\title{
The Stuff of which Dreams are Made: Representations of the South Sea in German-language Tourist Brochures
}

\author{
Matthias Schellhorn and Harvey C. Perkins \\ Social Science, Tourism and Recreation Group, Environment, Society and \\ Design Division, PO Box 84, Lincoln University, Canterbury, New Zealand
}

\begin{abstract}
The ways in which the South Pacific islands are represented in German-language tourist brochures is investigated. Our discussion of these brochure representations will examine the contrasts between tourism advertising imagery and the day-to-day interactions of tourists and locals in the islands represented. Informed by literature on motives for travel, tourist brochures, place promotion and commodification, we will discuss how German, Swiss and Austrian tourism operators depend on a deep-seated desire on the part of tourists to engage with a mythical paradisal Utopia. Common to many cultures, Utopia represents dreams of a better reality. We emphasise therefore that in addition to the now well-documented paradisal element of island tourism promotion, German-speaking tourists are enticed to the South Pacific by advertising references to it as a place where dreams may be fulfilled.
\end{abstract}

Keywords: tourist brochures, South Pacific Islands, paradise, Utopia, dream fulfilment, imagined geographies

\section{Introduction}

This paper reports an investigation into the ways the South Pacific islands are represented in tourism brochures printed in the German language. Eighteen 'South Sea' brochures ${ }^{1}$ published by German, Swiss and Austrian travel agencies serve as case study materials for this purpose (Appendix 1). Our discussion of these brochure representations will examine the contrasts between tourism advertising imagery and the day-to-day interactions of tourists and locals in the areas represented. In doing so, we incorporate literature from tourism studies on motives for travel and show how such motives are directly connected to strategies of place promotion and associated processes of place commodification. We will discuss how tourism operators, acting as place promoters, incorporate historical Eurocentric place meanings and myths about the Pacific Islands into their tourism advertising brochures. Like so many place promoters of tropical tourism regions, German, Swiss and Austrian tourism operators depend on a deep-seated desire on the part of tourists to engage with a mythical paradisal Utopia. In their discussion of holiday culture, Swiss researchers, Müller and Thiem (1995) reinforce this point by interpreting travel as an image, a symbol or metaphor. Viewed in this light,

holiday culture in the specific form in which it has recently developed in the Western countries has taken over vital functions concerned with the establishment of identity. In particular, it satisfies basic needs in the sensual and 
emotional spheres for which industrial society makes virtually no provisions - myth, ritual and cyclical processes, positive Utopias. (Müller \& Thiem, 1995: 16) (authors' emphasis)

They argue further that the mythical character of the holiday culture manifests itself in the realisation of non-material needs - a dimension readily exploited by the advertising industry. Common to many cultures, Utopia represents dreams of a better reality. We also emphasise therefore that in addition to the now well-documented paradisal element of island tourism promotion, Germanspeaking tourists are enticed to the South Sea by advertising references to it as a place where dreams may be fulfilled.

As a starting point, we note that travelling to warm island beach destinations has long been a popular holiday pursuit for many Europeans. Mediterranean and Atlantic islands cater for a massive annual influx of predominantly Central European visitors and German-speaking tourists are well represented among them. Increasingly, over the last three decades, they have also chosen to holiday in resorts further afield, sometimes on the tropical islands of the South Pacific. In a geographical sense, these islands represent destinations which, for German-speaking travellers, could hardly be more remote. Since only two international carriers serve the region extensively, air connections from Europe are sporadic and the trip to the 'South Sea' ${ }^{2}$ still involves a very long and sometimes complicated journey. Yet in response to a perceived demand for such services, an increasing number of European outbound tour operators are now offering tours and booking arrangements for travel to these remote islands.

It is our contention that an understanding of what attracts German, Swiss and Austrian holiday-makers to travel to the South Pacific Islands may be gleaned from an examination of German-language tourist brochures. Goss (1993: 672), using Hawaii as a case study, suggests that advertisements for the Pacific Islands 'tell us more about the culture that produced them [advertisements] than that which they attempt to sell'. Thurot and Thurot (1983: 187) also believe that 'modern tourism is more of a narcissistic look at one's own culture than at others'. The tourism and travel industry uses multiple methods, techniques and media to promote a diverse array of products. No other medium, however, combines such a wide range of promotional objectives in one single operation as the tourist brochure. Because of this strategic efficiency, their wide distribution and market effectiveness, brochures have been described as representing 'tourism advertising par excellence' (Dann, 1993: 893). Sack (1992, quoted in King, 1997: 158-9) argues that 'advertisements are worthy of detailed study . . . because they constitute the language of consumption' which he describes as the 'most consistent manifestation of thought'. Only limited use has been made of brochures in tourism research, however (Buck, 1977; Dann, 1996). Research has been conducted into the brochure portrayal of Nova Scotia (Papson, 1981), Indonesia (Adams, 1984), Japan (Moeran, 1983), and Australia and Fiji (King, 1997). More recently, studies of representations in tourism have focused on tourism promotion generally and advertising media, including brochures, specifically. These contributions to the study of place image analysis support Dann's (1996) claim of it being a developing analytical process (Bruner, 1991; Cloke \& Perkins, 
1998, 2002; Cohen, C.B., 1995; Corkery \& Bailey, 1994; Crang, 1996; Crick, 1989; Dann, 1993, 1996; Hughes, 1992; Selwyn, 1990, 1993, 1996).

Related work has also been conducted on the production of island images in tourism. Of particular relevance to our study are studies by Goss (1993) and Wilson (1994) on place imagery and the production of paradisal island images. Also important are King's (1997) study of resort development in Australia and Fiji and Britton's (1979) research into the images of the Third World as portrayed in tourism marketing. Wilson (1994) examines the changing image of the Seychelles by comparing various historical periods representing discovery, colonisation and economic development of the islands. He notes that certain myths about, and stereotypes of, the Seychelles resulted from ongoing image construction and manipulation. He further identifies some of these stereotypes as being ideological products which support dominant power structures and therefore reflect European rather than local interests. This study also shows that sexual imagery can play a key role in the promotion of island destinations. Goss (1993) examines advertisements for the Hawaiian Islands and identifies specific recurrent elements of placemeaning. His analysis concentrates on the themes of earthly paradise, marginality, liminality, femininity and aloha. These 'topoi' or place-meanings frequently reflects perceptions of singularity and otherness. Interestingly, in the context of our study, Goss (1993) does not focus on 'dreams' as being a central advertising theme in his work. His findings are reinforced in the work of King (1997) and Britton (1979). Britton (1979: 321-3) argues that in the promotional images of Third World places, mystification masks reality. The exotic is amplified, with references being made to 'Eden' and 'sensuous', 'untouched', 'unspoiled' and 'paradisal' places and experience. To reinforce these images, industrial activities and urban areas are often left out of the picture. There is a fine line to be drawn between 'exotic' and 'uncomfortably different' and if there is potential for places to be perceived as too exotic, foreignness can be downplayed by omitting references to the local milieu. Regardless, Third World destinations in Britton's argument are all appropriated for the tourists' enjoyment with references to local poverty either being ignored, rationalised or romanticised. The exotic often incorporates the possibility of sexual liaison between locals and visitors (see also Scheyvens, 2002: 42-3) and is based on a disregard for any local sense of place with inauthentic place-making pervading many marketing materials.

King (1997: 2) develops a similar argument quoting Bloch (1959, vol 2: 890) as a basis for interpretations of the exotic island paradise: "'Dante, assuming a spherical form of the earth, even relegated it [paradise] to the antipodes of Jerusalem, into the South Seas"'. Organic images of island destinations are supplemented with deliberate tourism marketing which creates impressions of adventure and self-discovery. While some potential tourists might have menacing connotations of island experiences lurking in their subconscious minds derived from European fiction such as Lord of the Flies and Robinson Crusoe, marketers have systematically built up positive images of the islands. King (1997: 145) also argues that tourism promoters exploit the early literary work based on a Eurocentric island mythology noting that the fictional dream of paradise can become a reality for European consumers. As a result, consumer perceptions of South Pacific islands owe more to the mythology of the palm-fringed coral atoll than to the realities of life in the tropics. This is despite the fact that island environments and experiences are not 
always hospitable and include such things as coral cuts, sunburn, spiders, sharks, stonefish, sea wasps, and the cyclone season.

\section{Motives for Travel}

The search for a mythical paradise and dreams of Utopia relate to discussions of authenticity in the social scientific discourse on motives for travel in tourism. MacCannell (1976) viewed the tourist as a secular pilgrim searching for identity through authentic experiences in the Other. This search has been further interpreted by Graburn (1989) whose notion of a sacred journey illustrates the radical contrast between ordinary lives and tourism experiences. MacCannell built upon Goffman's (1959) dramaturgical front and back regions to develop the concept of staged authenticity which suggested that tourism often stages pseudo-authentic experiences in order to manipulate and profit from the identity-seeking tourist. This process leads to the gradual development of tourist spaces, a contrived sphere removed from the day-to-day local life. Cohen's (1972) addition to this debate focused on the role of the unknown Other in determining the tourist experience. This concept viewed tourism not so much as a secular pilgrimage into a pseudo-authentic world of staged attractions but rather as a conscious exploration of difference. For Cohen (1972: 165), the experience of unknown sights, customs and cultures represented an appreciation of strangeness and novelty 'valued for their own sake'.

In later work, Cohen (1979) developed a 'phenomenology of tourist experiences' comprising five tourist types striving for different recreational experiences according to their subjective ideal position relative to the centre of their home societies. The other (holiday) world of a strange encounter in these terms constitutes merely one end of a motivational spectrum. Cohen's model stretches all the way from familiarity to strangeness, from the organised mass tourist preferring familiar holiday surroundings to the wandering drifter who seeks immersion in a strange host culture.

As a result of Cohen's work, writers began to investigate tourists' motives and desires from a variety of perspectives. Importantly, links were made between the notions of otherness and playfulness in tourists' motives (Cohen, 1985; Gottlieb, 1982; Moore, 1980; Wagner, 1977). The tourist in these terms engages in the playful quest for an inversion of ordinary everyday life experiences. Those aspirations and values which cannot be fulfilled at home are instead pursued in the more or less contrived world of tourist attractions. The new pilgrimage is acted out in a ludic manner. Consequently, Cohen (1995) noted the increasing popularity of attractions which are contrived, often reconstructed, imaginary and, therefore, less place-bound. The current trend towards contrived attractions reflects the emergence of a postmodern ethos allowing Cohen to conclude that, 'If the culturally sanctioned mode of travel of the modern tourist has been that of the serious quest for authenticity, the mode of the post-modern tourist is that of a playful search for enjoyment' (Cohen, 1995: 21).

In recent years, postmodern themes have strongly influenced the social scientific discourse on tourism (see Cloke \& Perkins, 1998, 2002; MacCannell, 1992; Selwyn, 1990, 1996; Urry, 1990, 2002). The enjoyment of surfaces, sensations, spectacles and simulations is generally seen to perpetuate superficial clichés and 
fetishes. In MacCannell's (1992) interpretation, the prominent quest for shallow enjoyment encourages radically individualistic ideologies. Tourist travel in these terms has become a symbolic search for the true self. Selwyn (1990: 24) focuses on the transformational effect these processes have on tourism destinations. He notes that for many tourists, travel sites are no longer sources of biographical and historical meaning. Instead, they have become placeless and atemporal 'centres of physical and emotional sensation'. Many attractions therefore become progressively similar whether or not they are natural or contrived (Cohen, 1995; Urry, 1990, 2002). The world of tourism is perceived as an increasingly homogeneous yet constantly reinvented cultural construct.

Despite this, and in an attempt to defend the mass tourist from Boorstin's (1964) accusation of the tourist having the hopelessly undiscerning attitude of a cultural dope, Cohen (1995) rejects the view of the post-modern tourist as being a naive, unwitting or unconscious traveller. Instead, Cohen (1995: 25) suggests an inherently reflexive attitude when he paints the picture of tourists as 'sophisticated individuals who choose not to discern, though they are aware of the possibilities of distinction'.

The theme of reflexivity features strongly in the writing of Urry (1990, 1995, 2002). This work is based on the Habermasian tradition (1981) which emphasises the fact that individuals consciously assess the conditions of their life-worlds. Such reflection is usually seen as involving either a cognitive or a normative process. Urry (1995: 145), however, highlights a further dimension: ' . . . reflexivity can also be aesthetic. This involves the proliferation of images and symbols operating at the level of feeling and consolidated around judgments of taste and distinction about different natures and different societies'. When visiting a destination, therefore, a tourist experiences not just the physical place but also perceived representations thereof (see also Cloke \& Perkins, 1998).

Urry also focuses on daydreaming as an important aspect of most consumption processes and suggests that it holds a central role in much holiday-making. This form of daydreaming, however, is not purely an individual game but rather a socially organised activity reinforced by such practices as advertising and photography. As the subconscious recipient of diverse symbolic messages, Urry's traveller is acting out aesthetic reflexivity in a mainly visual manner through the process of a 'tourist gaze' in particular places (Urry, 1990, 1995, 2002). The role which tourist advertising images play in the context of gaze anticipation, place representation and actual tourism experience and performance in places like the Pacific Islands therefore relates to processes of place promotion and the reinforcement of paradisal mythology.

\section{Place Promotion}

The construction and marketing of place images constitutes an important element in tourism production processes. Consequently, tourism destinations are fundamentally part of global marketing. Since personal interpretation plays an important part in the acquisition of product information, it becomes the target for place-marketing. Producers of place-marketing, in the case of this study, brochures, manipulate people's perceptions by controlling the mental images tourist places evoke. In his investigation of 'social spatialization', Shields (1991: 
60) describes place images as 'the various discrete meanings associated with real places or regions regardless of their character in reality'. Once stereotyped and labelled in this way, places become identified in terms of strong core images (Cloke \& Perkins, 1998). Widely shared sets of such place images collectively comprise a 'place-myth' (Shields, 1991: 61).

What, then, are the origins of such myth-making? The literature distinguishes between 'organic' and 'induced' place images (see Britton, 1979; Dann, 1993; Gunn, 1972), the former being derived from traditional sources such as the news media, literature, education or popular culture. Induced or projected images usually result from conscious promotion efforts. Garcia (1988) points out that many promoted myths pre-date the tourist literature and some are rooted in films, books and romantic fiction. Examining changing brochure images of the Seychelles, Wilson (1994) traces some of the more prominent markers more than 100 years back to early colonial records of then dominant cultural and social conditions. During her study of Toraja attractions, Adams (1984) discovered mainly reworked indigenous ethnic markers, albeit in highly modified and often hardly recognisable permutations.

These case studies indicate that the organic and projected image categories are not discrete. Many images induced in the conscious effort of promoting places draw their myths from sources of organic imagery (Schöllmann et al., 2000, 2001; Smith, 1989). King (1997: 2-3) argues that organic images are 'supplemented by deliberate tourism marketing' and that 'consumer perceptions owe more to the mythology of the palm-fringed coral atolls than to the realities of life in the tropics'. As producers of tourism brochures convert resources into products, they interpret places (Dietvorst \& Ashworth, 1995). Such interpretations may reflect particular historical, often ethnocentric perspectives (Smith, 1989). In the context of tropical island promotional myth-making the ancient theme of an earthly paradise has, at least in the South Pacific Islands, become the most widespread and influential of all touristic place-myths (Cohen, 1982). This powerful core image is particularly relevant to our study, since the symbolism of paradise clearly influences much of the promotional discourse on the South Sea.

\section{The Myth of Paradise}

Exploring the nostalgic longing for paradise as an archetypal human condition, Cohen (1982) offers a comprehensive documentation of this symbolism in the tourism context. While the ancient symbol lost much of its original religious meaning through secularisation, tourism, interpreted as the search for a benign Other, represents one significant, albeit impoverished, expression of an originally religious longing. Today's paradisal symbolism promises foremost commercially appealing experiences staged at 'marginal paradises' (Cohen, 1982: 7). Being geographically and culturally remote, the touristic paradise offers a temporary refuge from an intense, complex and essentially unnatural modern life, characterised in the case of this paper as the experience of industrial central Europe. The quest for paradise has successfully been transposed from the realm of religion to that of mass consumption. 
The change in the paradisal experience is matched by a change in its symbolic meaning. Originally, paradise represented the archetypal and ultimate Utopia which derived significance partly from its unrealisability. As this symbolism transforms into a consumer product, however, the ultimate Utopia becomes a disenchanted ideal. What has previously been beyond reach can now be experienced. In this context, Cohen (1982: 9) reminds us:

The important point to note about 'realized Utopia' is that its 'realization' is made possible not only, and sometimes not at all, by an approximation of social reality to the ideal; but also, and often primarily, by a vulgarization of that ideal.

Cohen (1982: 10) notes that international advertising, reflecting a traditional link to Western philosophical thinking, has applied the paradise idea most often to islands. To him 'the Pacific Islands are one of the most outstanding examples of such an evocation and exploitation of an ancient theme for the development of modern tourist destinations'. Studying the history of the mythical image in this context, Cohen describes a series of modifications to the ancient multivocal theme. A gentle paradise representing the benign aspects of the Other is the dominant theme in the marketing of Polynesia. A primeval wilderness image representing a rather threatening aspect of the Other characterises eastern Melanesia where Papua New Guinea is seen as the last frontier of primitive culture. Of particular interest in this context is the tendency of island-based tourism operators to match their touristic realities to the image projected upon them. Cohen (1982: 16) cites the 'pseudo polynisation' of Fiji as an interesting example of tourism-related cultural adaptation. As the gap between images and island reality widens, new versions of the earthly paradise are artificially reproduced. This is the only way the islands can continue to provide refuges for the unfulfilled mythical desires and Utopian fantasies of modern people. By matching these touristic expectations, the (re)constructed paradisal realities facilitate the transformation of Utopian myth to consumer product.

The construction and promotion of place-meanings and utopian place-myths clearly benefits the selling efforts of tourism enterprises (Dann, 1993; Selby \& Morgan, 1996). Earlier research confirms a strong link between the perception of a destination and the purchase decision of the consumer (Pearce, 1982). Various authors emphasise the role that promotional materials and their constituent imagined geographies (Valentine, 1999) hold in the ongoing commodification of tourism places (Cloke \& Perkins, 2002; Corkery \& Bailey, 1994; Goss, 1993; Hughes, 1992; Meethan, 2001). Interpreting from a post-structuralist viewpoint, Selwyn (1993: 127) describes commodification in the context of tourism brochures as 'the gathering of everything, from sites to emotions to persons, into the cash nexus'.

\section{The Commodification of Tourist Places}

King and Stewart (1996) analyse the marketing process and its powerful role beyond the initial shaping of tourist anticipation. The authors conclude that the promotion and consequent commodification of tourist places has far-reaching effects not only on the economic but also on the sociocultural realities of host 
communities. The promoted images and (resulting) expectations held by tourists are seen to be central to this transformation process:

In many ways, travel opportunities have come to be packaged experiences that are sold as commodities to a consuming culture. Not only can adventure be packed into two weeks, but the well defined expectations are guaranteed! . . . The tourists come to the host community not only with their expectations, but also with the economic power to fulfil them. (King \& Stewart, 1996: 295)

Image-making and commodification are linked to the ways places change symbolically and physically (Cloke \& Perkins, 1998, 2002; Dietvorst \& Ashworth, 1995). Producers transform tourism resources not only on a physical level through direct management actions but also on a symbolic level through place-marketing. Furthermore, the physical and the symbolic elements of tourism-led changes are often made consistent with successful marketing images of places (Cloke \& Perkins, 1998, 2002; Shields, 1991). A similar claim is made by Lewis (1979: 21) with specific reference to promotional travel literature acting as an 'agent of landscape change'. The author cites the upgrading and sanitisation of the French Quarter in New Orleans as an occasion where tourism advertising has become a 'self-fulfilling prophecy'. In a similar vein, Thurot and Thurot (1983: 176) argue that advertising 'has little by little led the people's stories to conform with the discourse [of advertising] itself'. Writing earlier, MacCannell, (1976: 110) pointed out that 'usually, the first contact sightseers have with a sight is not the sight itself but representations thereof'.

Markers which function as visual, locational or contextual designations authenticate advertised information about a destination. The Indonesian case study by Adams (1984) illustrated how select cultural markers, such as funeral celebrations or buffalo sacrifices, become ethnic stereotypes through which advertisers indicate authentic tourist experiences. Singled out and packaged, these stereotypical markers provide a 'mental grid' through which travellers filter their perceptions (Adams, 1984: 469). On site, the tourist's expectations and the tour operator's corresponding programme reflect these preconceived images. Anticipating myths have become (staged) realities.

Within tourism, commodification can therefore be conceptualised on two interrelated levels. It occurs in terms of the representations of tourist spaces (through images and associated preconceptions) but also at the level of lived experience (in the form of corresponding narratives, physical developments and actual tourist-host experiences). As Meethan (2001) points out, however, the fact that experiences are mediated through forms of commodification does not necessarily diminish them, a conclusion shared by several other authors (cf. Cohen, 1988; Dahles \& Van Meist, 2000; MacDonald, 1997; Stymeist, 1996; Wood, 1997) and supported by the case studies discussed below. Such non-normative assessment of the commodification process presupposes a perception of consumers as active agents capable not only of reflexivity but of drawing from experiences as sources of self-identity (Giddens, 1991). A similar understanding of the creative potential in tourism consumption also guided our brochure research and will therefore inform the remainder of our discussion. 


\section{Methodological Approach}

This paper has its origins in our ongoing research into tourism in the South Pacific region. Our work is also informed by tour-guiding work one of us (a German immigrant to New Zealand) has conducted with Swiss and German tourists in various islands of the Pacific and Australasia over the past 15 years. The research began with the observation that German-speaking tourists often had a curious, somewhat 'romantic' interest in visiting the distant South Pacific islands. Confirmation of this was sought on a trip to Germany, Switzerland and Austria in 1998, at which time visits were made to travel agencies and tourism operators to gather documentary material. Available German-language tourism brochures advertising travelling opportunities to the South Pacific islands were collected as part of that exercise. They form the raw material for our observations in this paper.

Once having examined the brochures and translated them from German to English, our primary objective was to identify the visual and textual messages contained in them and to categorise their major themes. Our interpretation of those themes was influenced by elements of content analysis (Kassarjian, 1977), discourse analysis (Parker, 1992), and deconstruction (Soule, 1995). We first interpreted the contents of the brochures using quantitative techniques. This descriptive content analysis 'led us' into the research data. This process focused on the photographs contained in the 'South Sea' sections of each brochure. In total, 986 photographs were systematically categorised and the resulting data listed in tables. Paying special attention to the meaningful creation of analytical categories, the content analysis concentrated on the visual representation of people but also incorporated built and natural landscapes. The examination of visual materials provided a working typology of themes and, thereby, led us on to identify specific promotional place images and myths. Following this initial content analysis, we cross-checked and supplemented these data by critically analysing representative brochure texts contained on 365 brochure pages. For this secondary analysis, we widened our approach beyond pure item counts and focused both on emphatic themes and issues that were clearly of importance in the context of life in the islands of the South Pacific but about which brochure writers remained silent. The resulting qualitative analysis, following Felsenmeier and MacKay (1996: 39), focused on 'language, author, reader, text, history, interpretation, meaning, and context'. Since they question emerging authority, deconstructionist techniques are obviously well suited to the critical examination of the symbolic transformation processes evident in destination marketing. In this analytical context,

... deconstruction is being employed as a means of inquiry to examine the politics of image, to reveal destination marketers as 'authors' of this image, and to provide a framework for uncovering the implications of reconstructing destinations based on idealised images. (Felsenmeier \& MacKay, 1996)

This led us to consider the asymmetrical economic relationship between hosts and guests in developing countries and noted that a diverse range of socioeconomic 
repercussions have been suggested. Some writers have characterised tourism in this situation as being a form of imperialism (de Kadt, 1979), as an agent of neocolonialism (Britton, 1982) or as an obstruction to development (Lea, 1988). Authors who have approached the commodification of places within the wider context of cultural change have written about tourist intrusion into the host culture and detected a shift from intrinsic customary values to artificial exchange values (Cohen, 1988; Selwyn, 1993). For Dann (1996: 76), tourism is a concrete commercial reality built around massive movements of people. There is a requirement for control, both in an organisational but also in a political sense, since tourism operators want to secure their economic interests. Lea (1988) suggested that many indigenous cultures disapprove of their traditional life-sustaining practices being transformed into service activities in this process.

Our analysis of tourism brochures then concentrated on deconstructing the images and myths which are being sold in a particular place promotion context. In this analysis, we inevitably investigate the deceptive role of tourist brochures as promotional mechanisms for commercial control. In particular, the mythical, ritual and utopian character of travel and its specific contribution to modern cultural identification provide an appropriate and stimulating focus to our analysis of brochure material. The remainder of this paper will discuss the key results of this analytical work.

\section{South Sea: The Place of Gentle Discovery}

Brochure texts frequently refer to the famous European explorers of the South Pacific, particularly to Captain James Cook, who visited the island of Tahiti several times during his three voyages. There are significant connections between the various diaries which were written during this early phase of European exploration and the South Sea's modern touristic place image. Smith (1989) has argued that the diarists' work was supplemented by that of draughtsmen, painters, botanists and ethnographers who played a significant role in realising the scientific and logistic objectives of the European voyages and were important purveyors and shapers of the subsequent Pacific imagery. This relates directly to the 18th-century European imagination which put Europe at the centre of the 'known world' and placed 'Africa', 'Asia', 'America' and 'the Pacific' in positions of difference and deferral. In this context European exploration influenced the production of regional stereotypes (Smith, 1989: 4-5) and explorers' diaries, along with other forms of travel writing, were central in the discursive production of regions as bounded spaces and having particular identities, including landscapes. In this process the tropics became characterised as a zone of human abjection, excess and primaeval nature (Gregory, 2000; Smith, 1989), ideas closely related to paradise. Accordingly, Captain Cook, his crews and other Europeans, often felt they had landed in paradise when they explored the shores of Tahiti. Englishman Samuel Wallis was the first European explorer to sight the island on the 6th of June 1767 from his schooner Dolphin. A few days later the ship's master noted in his journal that ' . . . the country had the most Beautiful appearance it's possible to Imagine' (Robertson, 1955: 24). He also commented on the erotic appeal which the Tahitian women had to the eyes of the Dolphin's crew: 
' . . . all the sailors swore they never saw handsomer made women in their lives' (Robertson, 1955: 57).

No other explorer, however, is more explicit in his praise of the Tahitian landscape and its inhabitants than the French Captain Bougainville who reached the Society Islands in 1768 . He declared Tahiti to be an earthly paradise in the following entry from his journal:

I have often, in company with only one or two of our people, been out walking in the interior parts of the isle. I thought I was transported into the garden of Eden ... A numerous people there enjoy the blessings which nature showers liberally down upon them. We found companies of men and women sitting under the shade of their fruit trees: they all greeted us with signs of friendship: those who met us upon the road stood aside to let us pass by; everywhere we found hospitality, ease, innocent joy, and every appearance of happiness amongst them. (Bougainville, 1772: 228-9) (authors' emphasis)

Not just the Tahitian landscape but also its inhabitants are being associated with the Judaeo-Christian myth of paradise in this particular narrative. Bougainville was more specific in his use of mythical imagery when he described Tahitian women. One encounter, in particular, is often cited by the secondary literature and many analysts accredit it with the birth of the legend of Tahiti (Cameron, 1987). Whenever the French ship La Bordeuse anchored in a Tahitian bay, it was approached by Polynesian craft and, recording such an incident, Captain Bougainville noted:

The periaguas were full of females; who, for agreeable features, are not inferior to most European women; and who in point of beauty of the body might, with much reason, vie with them all. Most of these fair females were naked; . . . It was very difficult to keep at their work four hundred young French sailors, who had seen no woman for six months. In spite of all our precautions a young woman came on board, and placed herself upon the quarter deck ... the girl carelessly dropped a cloth, which covered her, and appeared in the eyes of the beholder, such as venus showed herself to the Phrygian shepherd, having, indeed, the celestial form of that goddess ... At last our cares succeeded in keeping these bewitched fellows in order, so it was not less difficult to keep the command of ourselves. (Bougainville, 1772: 218-19)

This original journal entry illustrates particularly well the mystification of the Tahitian female by associating her, in this particular instance, with the pre-Christian Greek mythos of Venus. The quotation also hints at yet another commonly alleged personality trait of the Polynesian woman, namely that of the polygamous erotic seducer. Bougainville (1772: 257) dwells on this topic repeatedly with remarks such as this: 'The very air which these people breathe, their songs, their dances, almost constantly attended with indecent postures, all conspire to call to mind the sweets of love, all engage to give themselves up to them'. Descriptions such as the examples quoted earlier occur throughout the journal of the South Pacific's early European explorers. Romanticising portrayals of the Polynesian female are not just evident in the written records of colonial 
discovery but also in many of the paintings produced by artists on board these voyages. Most colonial narratives and pictures endow Tahitian women and, as we shall argue, consequently the island itself and the South Sea at large, with an irresistible erotic power.

These romantic portrayals of the South Sea's inhabitants clearly supported the theories of the noble savage advocated strongly by contemporary philosophers of the French Enlightenment such as Rousseau and Diderot. The widely publicised travel journals, furthermore, provided a fertile base upon which stereotypical images of the exotic South Sea landscape and people could grow throughout Europe. Our analysis of German-language tourist brochures suggests that this theme of seductive power is still being perpetuated by much of the discourse on South Sea place promotion. Having identified historic roots of the South Sea's feminine place image in the context of male colonial perception, we shall now investigate the ways in which tourist brochures currently use the topos of discovery in their advertising discourse.

\section{Islands of Romantic Discovery}

The theme of discovery features prominently in South Sea brochures, particularly in the descriptions of vacation cruises. Readers are encouraged to identify with the colonial explorers: 'Aboard the luxurious cruise vessel Reef Escape you experience wonderful days and romantic nights. Only from the water will you experience the South Sea in the same way as the early explorers did' (Pacific Jet, 1997/98: 52).

As readers are invited to follow early European routes of discovery, both, the colonial voyages and the (neo-colonial) tourist journey are being romanticised. The description of a three-day sailing safari promises that ' . . you will feel your mind being turned back to the period of the legendary sailors. As in those days discover the blue lagoons, palm beaches and peaceful islanders, the true Fijians await you ' (Pacific Jet, 1987/98: 53). That the true Fijian males of pre-missionary times were often in fact fierce warriors remains an untold element in this particular narrative.

By romanticising colonial voyages, the brochures tell a partial truth which simply ignores all the historic confrontational encounters between the Pacific people and early European explorers. Many of these historic conflicts ended in a tragic loss of life for both the colonisers and for the colonised. Notably, the voyager who features most prominently in the brochure texts, Captain James Cook, was clubbed and stabbed to death on a Polynesian beach in 1779.

\section{Discoverers and the discovered}

Unlike colonial times, however, there is never any doubt today that exploring tourists will always be welcome, whether it is the cultural or natural environment that attracts them. Readers are assured that in fact the 'island diversity invites discovery' (Feria, 1997: 7) and 'picture book villages, white dream beaches with crystal clear waters and turquoise lagoons await you' (Tischler, 1997/98: 10). Even more explicit is the suggestion that 'lovely landscapes, thundering waterfalls and picturesque villages want to be discovered' (Imholz, 1997/98: 97) (all emphases in this paragraph ours). 
Readers who have explored any South Pacific island by foot will know that the discovering of 'picturesque villages' is a sensitive issue. Local custom requires that visiting strangers follow certain behavioural rules. Thus, some form of symbolic exchange or a traditional welcoming ritual such as a kava ceremony may be asked for. The village, represented by its chief, performs a very active role in such an event. Unsolicited village explorations are considered disrespectful and careless sightseeing is likely to cause cultural affront. The brochures, however, make no mention of such cultural etiquette. Instead, they promote an active form of discovery based solely on the principle of recreational enjoyment: 'Even Captain Cook was inspired by the beauty of Moorea. Lush vegetation, steep rock walls. Enjoy once more the magic of the South Sea. Whatever you feel like doing, just do it' (CA Ferntouristik, 1997/98: 213) (authors' emphasis).

Contrary to the ritual traditions described above, brochure texts present local villages and their inhabitants generally as the willing and passive hosts of tourist activities. Village life, central to local cultural identity, is often characterised as being a museum exhibit. The brochure introduction to Huahine island is particularly explicit: 'Small villages with simple colourful houses, the lakeside village of Maeva, an open air museum par excellence' (Hotelplan, 1997/98: 80). The uninhibited tourist gaze is openly encouraged, while the sightseeing promoted does not seem to concern itself with boundaries of privacy. The traditional open fale found in Samoan villages does not offer walls to protect inhabitants against prying tourist eyes. In local custom, passers-by are encouraged to ignore discreetly the private scene he or she might encounter when entering a village - not so the newly arrived tourist in the Feria brochure (1997: 7):

Talofa - welcome to Samoa. This is how the friendly Samoans greet every guest and friend. From the airport the road takes you to Apia, past palm coves, gently rising hills and Polynesian villages which offer a direct insight into family life. (authors' emphasis)

Portrayed as 'forgotten paradises' (Hotelplan, 1997/98: 82) waiting to be discovered, enjoyed, gazed at and ultimately consumed, the islands (and their inhabitants) hold a distinctively passive role in the brochure's representations of tourism. This portrayal corresponds to the connotation of passive femininity discussed earlier. Resembling colonial times, the brochures leave no doubt as to who is doing the discovering and who is being discovered ...

\section{Islands of a gentle nature}

The selective narrating of the local people's stories finds a parallel in the one-sided portrayal of the South Sea's natural history. The brochure texts offer modern-day discoverers a gentle and almost sensual experience, no matter where their explorations will take them. Thus the traveller is promised to find ' ... a slice of heaven on earth. Green islands surrounded by white sand, where there are neither snakes nor beasts of prey. Yet there are clear seas with rich fishing grounds, lush flowers, juicy fruits' (Kiwi Tours, 1996: 40-41).

In contrast, the Pacific's diverse marine environment also includes various species of shark, including the larger tiger shark whose attack on a snorkelling 
New Zealand tourist has recently made headlines (Keenan, 1997). Shark attacks attract much media attention. Other, often far more hazardous dangers of Pacific waters, however, are less publicised. In their extensive treatise of Pacific health aspects Rudkin and Hall (1996), for example, list a number of poisonous marine animals such as stonefish, stingrays, jellyfish, fire corals and sea snakes to which the famed turquoise lagoons of the travel brochures offer an ideal habitat. Additionally, painful tissue infections are one of the most common health problems which European tourists encounter in Pacific islands. Serious ulcers often develop from minor scratches, cuts, bites or stings. Lonely Planet's 'Travel Survival Kit' to Samoa traces such infections to the warm, moist conditions of the tropical lowlands and the micro-fauna of the Pacific Ocean in particular:

Since the waters of the Samoas are full of staphylococcus bacteria, it is best not to swim with an open wound. Staph infections are miserable and are very difficult to treat. Sadly, many villagers in the Samoas die of such infections that have ulcerated and spread to vital organs. (Swaney, 1994)

In the glossy travel brochures, stories such as these naturally remain untold, since they would darken the crystal clear waters of the gentle island world which the tourism marketers wish to promote. Instead the advertisers prefer to promise 'soft light and water temperatures, which don't chill but caress' (Kiwi Tours, 1996: 50).

What exactly, then, is this contrived gentle island world of the South Sea? Again, the advertiser offers a clear answer:

Until today the South Sea has remained a paradise. With first class hotels. Peaceful and safe. Here ranks as rich, who gives, not who owns. Maybe that is why the islanders have maintained their cheerful, relaxed life style. Take a slice of it home with you. (Kiwi Tours, 1996: 40-41)

The portrayal of the South Pacific islands as an earthly paradise runs through the brochures like a dominant thematic thread. The next section of our analysis, therefore, will focus on this theme in some detail.

\section{A Brief Anatomy of the South Sea Paradise}

The travel brochures never leave the slightest doubt that the South Sea is indeed a heaven on earth. Feria offers some glimpses into this paradisal world right at the outset of its catalogue. Under the bold heading 'Every island a paradise' the brochure features an initial double page description of various island groups, beginning with the ambiguous suggestion: 'Let yourself be seduced by the diversity and variety of French Polynesia ...' (Feria, 1997: 6).

All brochures thus illustrate the promise of paradise with much visual material. Photographs show deserted palm-lined coral beaches or tranquil turquoise lagoons. Frequently, aerial shots of islands and atolls create a fantasy-like image. People also feature in paradise: we constantly find the ubiquitous polynesian seduction in the form of young flower-adorned women. Innocence, fun and play are often conveyed by the images of young children. One brochure represents the 
classic Garden of Eden theme by using a lush jungle scene towering above a lonely tourist couple (Feria, 1997: 6). If these visual images share a common theme, it is the promise of a genuine and unspoilt paradise beyond our everyday reality.

\section{Paradise on the margin}

The term 'South Sea' is a rather vague descriptor of the islands of Oceania since it is geographically undefined. While some brochures include in this region the Hawaiian Islands, eastern Melanesia and sometimes Micronesia, others place the South Sea closer to the centre of the Polynesian triangle and western Melanesia. Obviously, the term carries more of a symbolic than a defined geographic meaning.

Advertisers commonly mystify the geographic location of the South Sea and sometimes place South Pacific islands 'half way between Australia and America' (Knecht Reisen Ozeanien, 1997/98: 102). On the other hand, the brochures often mention the wideness of the Pacific and highlight the fact that the islands are spread over a large area of water. Glowing metaphorical language frequently supports such mystification, as this introduction to the region illustrates: 'Like stars on the nocturnal firmament, more than 25,000 islands are spread out over the endless expanse of the Pacific' (Klingenstein, 1996: 116).

Visually, the mystification is reinforced by 108 aerial photographs, most of which show an entire island surrounded by vast ocean waters. Often, these images depict atolls and their colourful lagoons from a far distance. This geographic mystification is taken to an extreme in the Jumbo Touristik brochure (1995/96: 61) where a reconstructed satellite image shows the South Pacific Ocean on such a large scale that most islands cannot be located. White cloud bands add a further touch of mystery while the accompanying text encourages readers to 'experience the magic - not just in the fantasy!'

The catalogue page reproduced in Figure 1 presents the classical cliché of a South Sea landscape. Under the heading 'The Dream Islands of the South Sea', we view a turquoise lagoon set amongst the outer reaches of a coral atoll. So daringly close appears the Pacific horizon that, no doubt, the viewer's mind instantly transposes itself to the very margin of our geographical world. The text directly below the photograph carries this theme further still by referring to the South Sea as the opposite side of the earth, a place 'far away from civilization, where the world is still intact' (Kuoni, 1997/98: 80).

The South Pacific islands are marginal to Central European perception in many ways. Located near the international dateline, the islands occupy the margins of its time sphere. The brochures also marginalise the South Sea in temporal terms by portraying their traditional societies as socioculturally less developed. Furthermore, the exotic island images described earlier represent an alien and distant world which challenges European cultural concepts. In many ways, then, the brochures' representations of paradise transcend our everyday reality and reach for the outer periphery of imagination. Thus, the image of the South Sea, as constructed by the brochures, addresses itself primarily to that mental realm we reserve for a Utopian dream. Only there can we expect a paradise intact. 


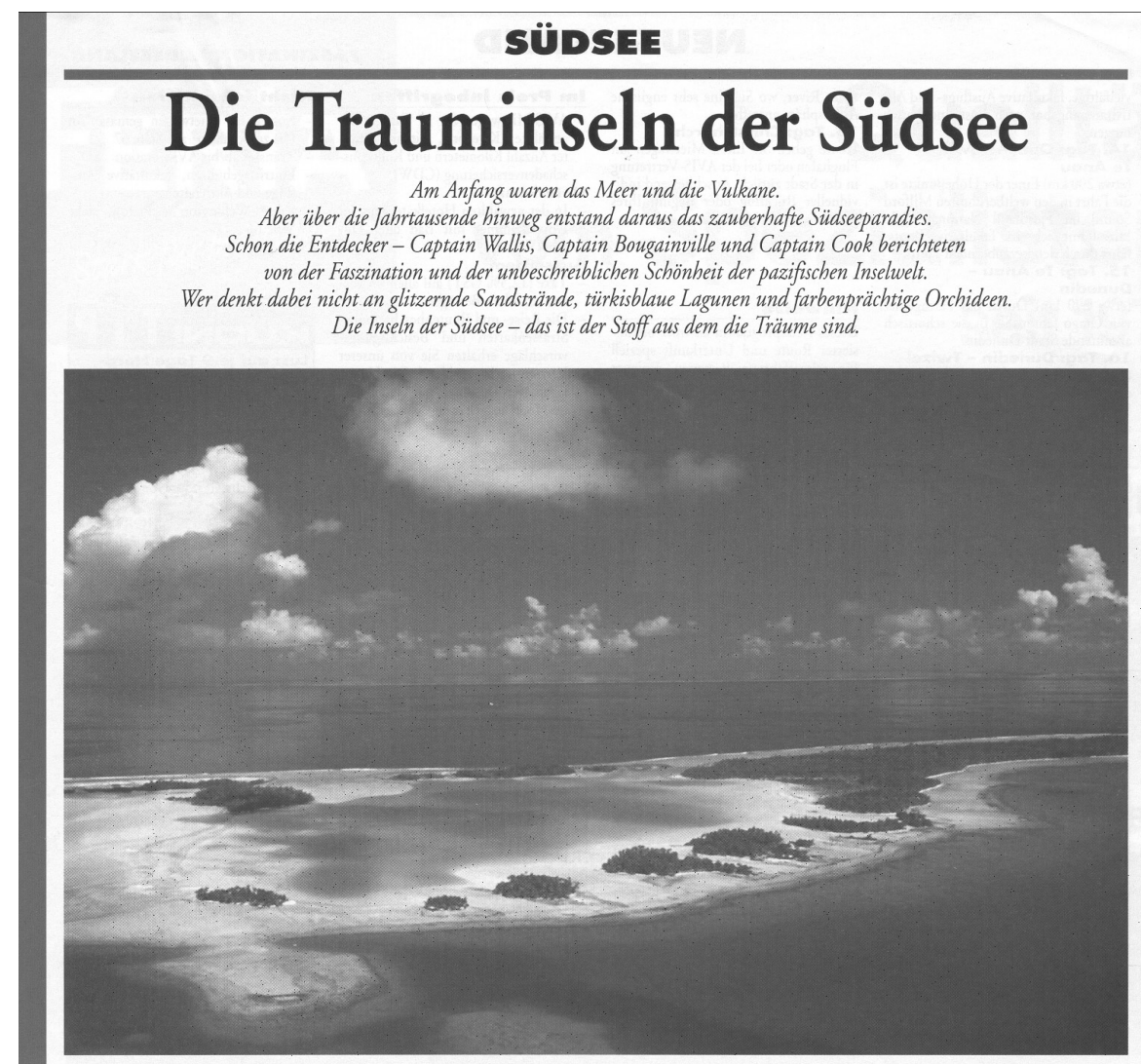

Der Pazifik ist der grösste aller Ozeane. Mit seinen Ausmassen übertrifft er die gesamte Landfläche unseres Planeten. Er bedeckt mehr als ein Drittel der Erdoberfläche und in seinem Gebiet liegen etwa 30000 Inseln. Sie reichen von winzigen Atollen bis zu grossen Vulkaninseln, die sich aus dem Meeresboden erheben. Abenteuerliche Entdeckungsfahrten und unzählige Romane brachten die Kunde von den sonnigen Inseln und

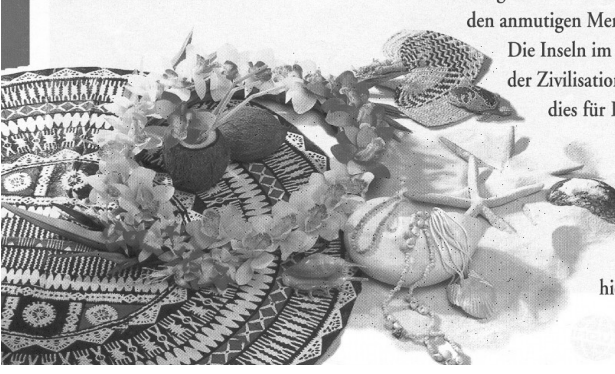

Figure 1 The dream island of the South Sea

Note: Directly above this picture in the brochure is the line: 'The islands of the South Sea - this is the stuff from which dreams are made'. It is helpful to remember to whom these brochures address themselves. In this particular case, we are looking at a travel catalogue designed by the largest travel agency operating on the Swiss market. For most residents of land-locked Switzerland, the colourful and mysterious picture of a Pacific atoll would promise far more than just another island scene. In a symbolic sense, this image of a marginal paradise represents nothing less than a distant fantasy. Utopia, then, is the stuff from which the dreams are made in this particular instance (Kuoni, 1997/98: 80). 


\section{Paradise unspoilt}

Overall, 22 brochure photographs (see Table 3) feature local children, usually adorned with flowers. Their joyful faces convey the impression of lightness and playfulness associated with the 'real and genuine South Sea paradise' the brochures want to sell (Rast Reisen, 1997/98: 13). These smiling children also promote an image of innocence and purity associated only with an intact paradise. Brochure texts, accordingly, reinforce notions of unspoiltness, referring not only to the islands' landscapes but also to their populations: 'Here you still find real, unused Polynesia with all its fascinating myths and the natural friendliness of the inhabitants' (Pacific Jet, 1997/98: 84).

The islands' inhabitants become yet another signifier of paradisal pureness, as indicated by the following cruise promotion: 'Blue Lagoon is a special experience. One experiences skin deep the untouched island world of the Yasawas and gets in contact with the unspoilt South Sea people' (Knecht Reisen Ozeanien, 1997 / 98: 99). This particular group of 16 main volcanic islands has been romanticised in two feature films produced in 1949 and 1980. The film's title Blue Lagoon has since become the trademark of Fiji's most popular tourist cruise.

The Yasawa islands, similarly described in another brochure as 'still untouched and almost devoid of people' (CA Ferntouristik, 1997/98: 202) actually support a population of about 2000 inhabitants. The Yasawas' landscape has been severely modified through deforestation. Remnant pockets of the original forest cover are restricted to steeper slopes while secondary grassland is the dominant vegetation type elsewhere. Contrary to the glossy brochure image of an untouched paradise, this impoverished cultural landscape indicates a history of severe resource exploitation.

Since arable land is limited, several of the Yasawas' villages today derive their income mainly from tourism (Kay, 1993). The South Pacific Handbook advises travellers wishing to stay in the Yasawa island of Tavewa in the following manner: ' ... there is tremendous jealousy and rivalry among the families of Tavewa. One group often berates the other to visitors - don't let yourself be taken in by it' (Stanley, 1993: 536). Obviously, tourism development is having some impact on community relations. The resulting social conflicts shed a different light on the 'unspoilt host' image the brochures suggest.

\section{Paradise beyond time}

To emphasise Oceania's unspoilt image, the brochure writers frequently suggest that time has stood still in this remote corner of the globe. The advertisers differ in their assessment as to when this temporal vacuum could have begun. Suggestions range from 'heaven on earth - today exactly as 5000 years ago' (Kiwi Tours, 1996: 40) to much more recent dates, such as in the description of Maninoa as 'a still unspoilt Samoan village, where life hasn't changed much over the past one hundred years' (Pacific Jet, 1997/98: 103). In the most extreme scenario, however, time simply does not exist at all:

Die zeitlosen Inseln - 'the timeless islands' is the somehow free translation of our title. But Vanuatu is a place where the time really doesn't make any difference, a place for relaxation ... to visit Vanuatu is not a time lost, expe- 
rience the timeless land, we invite you to an unforgettable journey. (Knecht Reisen Ozeanien, 1997/98: 109)

The image of timelessness moves the South Sea paradise beyond the constraints of current affairs. In a timeless land, there is no room for conflicts and politics. Brochure readers, accordingly, are invited to visit a peaceful heaven: 'Experience the paradisal unconstrained lightness and enjoy the heavenly peace. You will feel how yesterday and tomorrow melt together' (Studiosus, 1997: 368).

Ironically, the term 'melting together' assumes an entirely different meaning in the light of Oceania's recent political and environmental history. A fusion of an explosive kind thrust the region into press headlines during 1995 when colonial France conducted a final nuclear test series below the Moruroa atoll, $1200 \mathrm{~km}$ south-east of Tahiti. Worldwide protest soon met this controversial decision and, in Papeete, led to a state of serious public unrest. During a period of several days, the international airport came under siege by protesters, forcing some airlines to suspend scheduled arrivals. These events prompted the regional magazine Pacific Islands Monthly (October 1995) to feature the title page headline 'Riots in Paradise'. Within a matter of a few weeks, the colony's entire tourism industry came to a standstill.

Political developments in Fiji over the past decade indicate that racial conflict has firmly established itself in this multicultural society. The term 'melting together', here also, assumes an explosive meaning when applied to the critical relationship between this country's two dominant ethnic groups of Indians and indigenous Fijians. Political coups in the 1980s and 1990s clearly showed the world that the tourist brochures' image of a 'timeless peaceful paradise' is built on an outdated stereotype. The ongoing political controversy over leased agricultural lands proves that racial tension remains unresolved in contemporary Fijian society. A recent newspaper article reports, 'Land is a racial and political issue in Fiji where about 90 per cent of the land is owned by native Fijians [sic] but leased to farmers who are mostly of Indian origin. The 30-year leases began expiring in September' (The Press, 1997). Time, obviously, is very meaningful for these particular islands of paradise.

\section{Paradise as the exotic escape}

Drawing pictures of an unspoilt, untouched and timeless paradise instead, the brochures make their readers believe that they are about to visit the 'last heaven on earth' (Pacific Jet, 1997/98: 66). This experience, so the advertisers promise, will have a profound effect on the traveller. CA Ferntouristik (1997 / 98: 202) provides us with a vague idea of the potential outcome:

The quietness, tranquillity and lucidity of this little paradise with a total population of 18,000 inhabitants, a smiling face whereever you arrive, hospitality and a relaxed atmosphere, let us recommend the Cook Islands as the tip of the South Sea. You will leave these islands relaxed and refreshed in body and soul and will have only one wish: to return as soon as possible. (authors' emphasis)

To have this refreshing and magnetic effect on visitors, the islands presumably provide a contrast to the hectic domestic everyday lives of Austrians, Germans 
and Swiss. As we have seen, the brochures leave no doubt that 'your little place in island paradise' (Meier's Weltreisen, 1997: 72) is worth aspiring to. It is this powerful lure of 'the exotic Other' on which our analysis has so far focused. The brochures, however, give various indications that their readers may also want to escape from certain aspects of their daily lives.

An Austrian brochure explains the appeal of Oceania stating that 'these heavenly islands of the South Sea have been spared from industry, terrorism and the illnesses of civilisation' (Jumbo Touristik, 1995/96: 61). Other texts present the islands as an antithesis to the frenzy or 'busy bustle' of everyday life (Pacific Jet, 1997 / 98: 56). More detailed is the following description of the Cook Islands:

In this island group are some of the few South Sea islands still preserved in their natural beauty. No TV, no traffic lights or high-rise buildings disturb the picture of this unique island world. (Rast Reisen, 1997/98: 78)

Brochures set the South Sea apart not only from physical aspects of modern civilisation but also in terms of lifestyle contrasts. Thus 'the supposed seriousness of life seems to have bypassed Moorea completely unnoticed' (Jumbo Touristik, 1995/96: 72). Differences in mentality are sometimes presented as challenging alternatives to Central European attitudes: 'It shouldn't be overlooked that the Western demands on service and especially on speed are often not met and also don't even want to be met by the locals. Stress and hectic activity are preferably left to others'. (CA Ferntouristik, 1997/98: 180) (authors' emphasis)

The ubiquitous romanticising of the islanders' lifestyle also includes commentary about poverty: 'We visit a long established family home and you will be surprised how one can live a rich life without money' (Klingenstein, 1996: 292). Many such references to local lifestyles and attitudes serve to extend the tourist journey beyond the physical to a mental level, hinting at possibilities for personal growth or even adjustments to inner values.

Descriptions of cruise holidays often stress their relaxed nature. Thus life on board becomes 'free and easy' or 'unconventional and splendidly uncomplicated'. Rast Reisen (1997 / 98: 13) is more specific in its cruise promotion: 'Experience four days' South Sea magic in an unconstrained atmosphere without dress code' (authors' emphasis). A rather hedonistic outlook on life is implied by the following text:

For one week you visit paradise, see magical Polynesian islands with mystical mountain tops ... whether Tahiti, Bora Bora, Huahine or Raiatea the philosophy is: 'To live means to enjoy'. (Jumbo Touristik, 1995/96: 73)

The escape from ordinary life to the promoted holiday world amounts to little more than a fast and smooth transition. Thus 'the worries of everyday life fade with the first tropical sundowner drink at the sea!' (Jumbo Touristik, 1995/96: 72). The prospect of returning from paradise, similarly, poses no problems. According to this brochure writer, coming back just involves a simple transfer:

At a farewell dinner you have the opportunity to reminisce about the diverse impressions of this wonderful journey until, shortly before midnight, the aeroplane will take you back into everyday life. (CA Ferntouristik, 1997/98: 212) 
That the average transfer between a Central European home and a South Pacific paradise amounts to a tiring journey of seldom less than 30 hours one way, remains untold by these glossy narratives. A glance at air timetables also reveals that many of the flights between island states arrive and depart at late night hours. Most of the advertised multi-island tour itineraries, therefore, involve sleepless nights spent in transit. Under those circumstances the exotic South Sea experience could easily prove quite unsettling to a stressed and dislocated traveller.

\section{Paradise as strangeness overcome}

Too much strangeness could threaten brochure readers. To counter this possibility, the tourism promoters reassure prospective clients that their journey to the exotic Other will in fact provide a safe experience. Such reassurance is transmitted in a number of ways. The lifestyles and attitudes to be found on the geographically and culturally remote islands of the South Pacific's cyclone belt pose a challenging antithesis to the orderly Swiss, Austrian or German life plan. The brochure writers recognise this and meet the potential for Angst with promises of security, comfort and reliability. Photographs of luxurious resort complexes, well appointed hotel rooms and smiling hosts all serve as promotional proof to this effect. Even crossings of the international dateline are carefully interpreted for the time-anxious Central European mind: 'Twice the dateline is being crossed, days are "won", days get "lost" and yet you reach home just at the right time' (Marco Polo, 1997: 272).

The tourism promoters must ensure that the exotic image of the South Sea that they are determined to uphold matches the expectations of a conventional market. The Imholz catalogue (1997/98: 88) illustrates this promotional challenge, with the rather suggestive offer to provide 'exactly what you always wanted - to get to know the South Sea romance yet not forego a certain comfort!' The critical bridge between image and expectation is not always easily constructed. Again, island residents hold an important role in this promotional effort. Where shortcomings in service are unavoidable, these are usually explained by the 'mentality typical of the country'. Customers are then asked to '... accept insufficiencies with a smile. The friendliness and the happy lifestyle of Tongans should be more important for the recreation-seeking guest than perfect organisation' (CA Ferntouristik, 1997/98: 184). Obviously, the local people are not only portrayed as available attractions but also become part of tourism's service periphery. Such labelling serves the purpose of transposing comfort expectations from the practical service level, where they obviously cannot always be met, to the realm of the tourists' psychological well-being. Mental attributes of the local people, therefore, function as key strategic elements in the advertisers' marketing of a safe and comforting paradise.

Occasionally, brochure texts draw from the multivocal nature of the paradise myth which Cohen (1982) has described. In the brochures surveyed, however, the wild, savage and dangerous side of the exotic Other is merely hinted at. These darker, almost hellish aspects of wilderness, serve primarily to build dramatic tension. Overall, the tranquil, sensual and comforting image of paradise dominates the advertising discourse. The following narrative shows how readers are 
made to feel at ease, in this particular case, by appealing to their sense of international friendship:

The sharply filed teeth of tradition-conscious Fijians should remind you that their ancestors loved to devour their visitors - but the flattering melodies of the ukelele, the flower leis and the naturally charming hospitality of the Polynesians not only welcome you in the Cook Islands, in Fiji and in French Polynesia but also in Tonga, where ties to Germany play a very important part. (Meier's Weltreisen, 1997: 73) (authors' emphasis)

The tension between the symbolic lure of romantic adventure and the desire for conventional customer comfort provides travel agents with yet another chance to advertise their own organisations. At the outset of the Feria catalogue (1997: 2), this travel agency clearly emphasises its important role as efficient service provider: 'The South Sea is simply fascinating and adventurous. So much more important is a good travel planning, care on location and perfectly organised transfers'. The headline statement 'Well informed into paradise' (Feria, 1997: 8) conveys the same message.

\section{The People of Paradise}

Tourism promotions construct place images from various physical and human elements. In this case, the presentation of Island people is used to fabricate a distinctive island image. Women, in particular, are shown to play an important part in the marketing of the South Sea as an exotic holiday destination.

Our initial quantitative analysis of visual brochure content produced as a first obvious result the absence of humans in the majority of photographs (Table 1). Almost two-thirds of all photographs surveyed do not feature people at all. This result is consistent with the marketing image of an untouched, unspoilt paradise noted in other studies of tourism brochures (Dann, 1996; Goss, 1993; Wilson, 1994). A closer examination of the remaining 'people photographs', however, reveals some interesting differences from earlier studies. In the 358 photographs of South Sea brochures which actually show people (Table 2), the local population is strongly represented: locals appear in more than half of all pictures in this sub-category. More significant still is the fact that about $42 \%$ of all ' people photographs' contain locals only.

Table 1 Human presence in brochure photographs

\begin{tabular}{||l|c|c||}
\hline Category & No. of photos & Percentage of total \\
\hline No people & 628 & 63.7 \\
\hline People & 358 & 36.3 \\
\hline Total & 986 & 100.0 \\
\hline
\end{tabular}

Table 2 People in brochure photographs $(n=358)$

\begin{tabular}{||l|c|c||}
\hline Category & No. of photos & Percentage of total \\
\hline Tourists only & 174 & 48.6 \\
\hline Locals only & 149 & 41.6 \\
\hline Tourists and locals & 35 & 9.8 \\
\hline
\end{tabular}




\section{Happy service people}

A closer look at the visual and written representations of the local population reveals that the pacific people are promoted as one of their islands' prime tourist attractions. Indeed, numerous text passages make reference to the islanders' laid-back, happy friendliness. These texts include locals as tourism resources, often listing them amongst other natural or, as the following example shows, even climatic features: 'Bula - welcome to the island realm of Fiji. Where the smile and the leisurely life rhythm of the people are so pleasantly obvious as the sunshine and natural beauty' (Hotelplan, 1997/98: 75).

Mental attributes such as happiness are often touted as tourist attractions and, thus, become expected expressions of the South Sea's wider service culture. Consequently, residents and their cultural practices are also used as compensation measures for inferior service standards. Consider the apologetic tone of the following brochure text:

Pardonable weaknesses in service are made up for by natural friendliness and whoever seeks the reality of the South Sea, will find it here, where the village head still governs like a chief, where old rituals and customs are often still part of daily life. (CA Ferntouristik, 1997/98: 169)

Less than $10 \%$ of the photographs featuring people illustrate tourists and locals together, a result consistent with earlier research (Dann, 1996). The brochure photographs clearly segregate hosts and guests. This promotional strategy reflects the nature of the advertising materials surveyed, since all the brochures are designed to sell packaged holidays. On most occasions when photographs show a cross-cultural interaction, the local people hold the role of smiling service providers or folk entertainers.

Only in a few instances do photographs display local-tourist interactions of a recreational character. These, then, occur either between a tourist and a group of local children or else between a solitary male tourist and one or two young, local females. Several such photos show male tourists conversing privately with local females, often subtly suggesting an erotic holiday encounter. We shall return to the important topics of gender relations and sexual imagery later. For the moment, let us have a closer look at the brochures' portrayal of the South Sea's female population.

\section{The brochure men and women}

Table 3 presents a quantitative categorisation of the brochure photographs which show local people only. Solitary women are the largest of various gender-based groups, nearly twice the size of the solitary men category. There is, however, not just a quantitative difference in the portrayal of unaccompanied local women and men. The local male is usually depicted within an active context, often engaged in professional or ceremonial activities that are integral to everyday domestic life. Thus a 'brochure man' might be fishing, working the gardens, climbing a coconut tree, mixing a kava bowl or patrolling in a police uniform (Figure 2). The stereotypical solitary 'brochure woman', on the other hand, is almost exclusively depicted as inactively 'just being there', often portrayed in close-up form posing for, or smiling at, the camera (and, ultimately, 

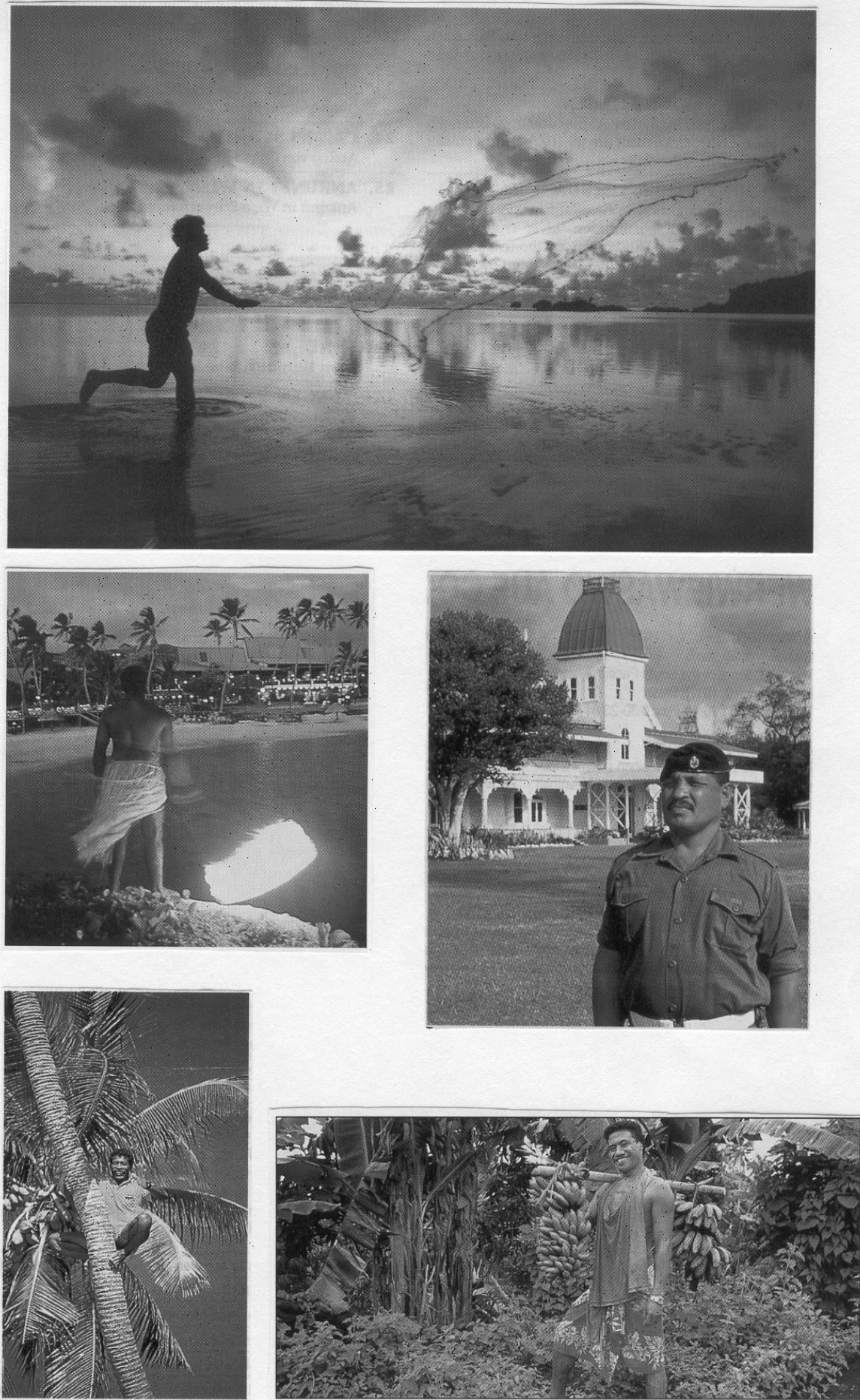

Figure 2 Brochure man 

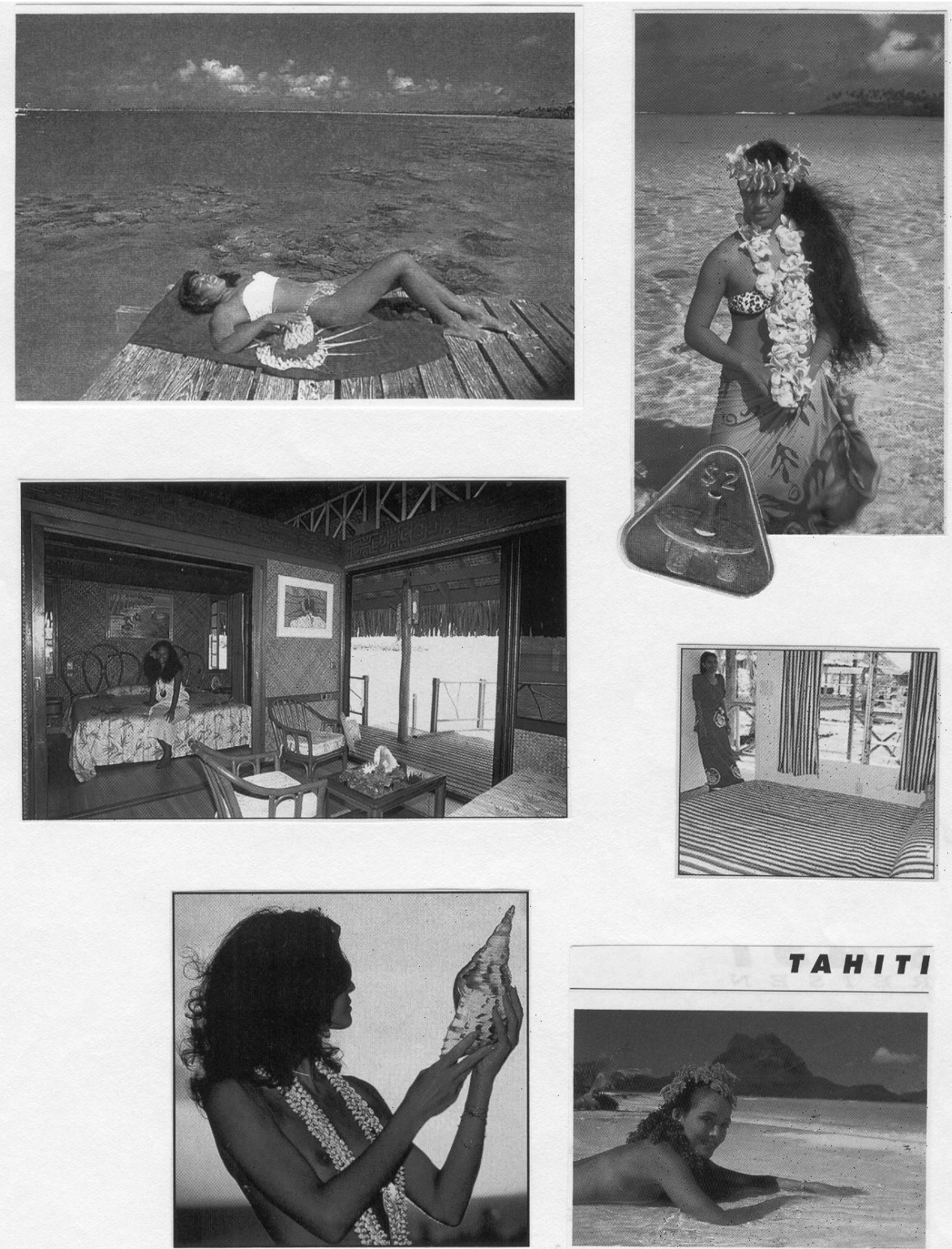

TA H I I

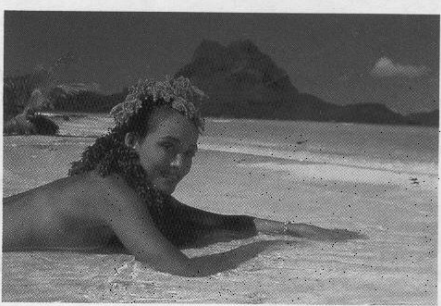

Figure 3 Brochure woman

the brochure reader). She might be lying on the beach or standing in the ankle deep waters of a turquoise lagoon. Occasionally, she sits in front of a hotel room or on a guest bed. In the few exceptions when a solitary woman is portrayed as working, she holds the role of servant, usually smiling over a tray of exotically decorated drinks (Figure 3). 
Table 3 Local people in brochure photographs $(n=149)$

\begin{tabular}{||l|c|c||}
\hline Category & No. of photos & Percentage of total \\
\hline Solitary woman & 39 & 26.2 \\
\hline Women only (2+) & 19 & 12.7 \\
\hline Solitary man & 20 & 13.4 \\
\hline Men only (2+) & 20 & 13.4 \\
\hline Solitary child & 4 & 2.7 \\
\hline Children only (2+) & 18 & 12.1 \\
\hline Mixed group & 29 & 19.5 \\
\hline
\end{tabular}

Anyone who has spent time on Pacific islands will have often seen village women engaged in hard physical labour. Women take a very active role in the local economy, particularly in the trading of market produce. At the same time, females carry the major burden of home work, family care and child rearing. Women also frequently contribute their time to community projects. This triple role of women, which has been noted in the literature on gender and development (Moser, 1993), means that South Sea's women are in fact very active and in most cases work harder than their male counterparts. Not so the stereotypical brochure woman. As the brochure photographs show, the advertisers clearly represent local women as passive objects. The following sections will investigate the purpose of this inaccurate portrayal in some detail.

\section{Women as authentic, available attractions}

In most of the 39 photographs featuring solitary local women, the person depicted has some of the following attributes. She is young (33 cases), wears a flower or plant ornament (32 cases), her bronzed shoulders are uncovered (30 cases) or she might wear a topless outfit (3 cases). The solitary local woman is not preoccupied; her portrayal as the smiling, attentive and, therefore, attractive host indicates more than just genuine hospitality. Equipped with the ornamental and sensual markings of an 'exotic other', this feminine host image also signals a 'genuine availability' which obviously extends to the realm of male sexual fantasy.

Sometimes markers of authenticity accompany a woman's portrayal. The solitary female might be holding a giant seashell, a colourful fish or some other exotic signifier of her truly tropical origin. Photo montages can be used to create a deceptive image. On the opening page of a brochure on the Cook Islands, a young polynesian woman kneels in the middle of a turquoise lagoon. Her long hair, colourful dress and tropical flower lei place this tourist destination within an 'exotic' physical context. As if to prove cultural authenticity, a local coin is partly superimposed on the portrait. Not only does the woman physically mark the destination's identity, but her image also becomes tourism's symbolic equivalent of island currency.

\section{Women as geographical markers}

The South Sea and its islands are often feminised in the brochures. Many written and visual images illustrate this strategy. Under the heading 'Bora 
Der Traum vom Südseeparadies - Französisch Polynesien mit Tahiti und seinen Inseln. Abenteuerliche Entdecker wie James. Cook, globetrottende Schriftsteller wie Jack London. Maler wie. Paul Gauguin und Schauspieler. wie Marlon Brando - sie alle schwärmten vom. Charme der anmutigen, sinnesfrohen Menschen und den märchenhaften Landschaften. 130 teils hügelige, überbordend tropische Eilande inmitten türkisblauer Lagunen und Korallenriffe, teils topfebene Korallenatolle mit palmenbestandenen, weissen Sandstränden und Innenlagunen, die mit dem offenen Meer verbunden sind, sonnen sich.im Pazifischen Ozean, auf halbem Weg zwischen Amerikas Westküste und Australien. Fün davon haben wir für Sie ausgesucht: Tahiti, Moorea Bora Bora, Huahine, Rangiroa - Inbegriff für Südseezauber und -romantik.

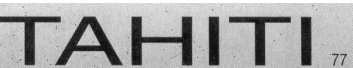

\section{Segelkreuzfahrt} mit der Wind Song

Wissenswertes

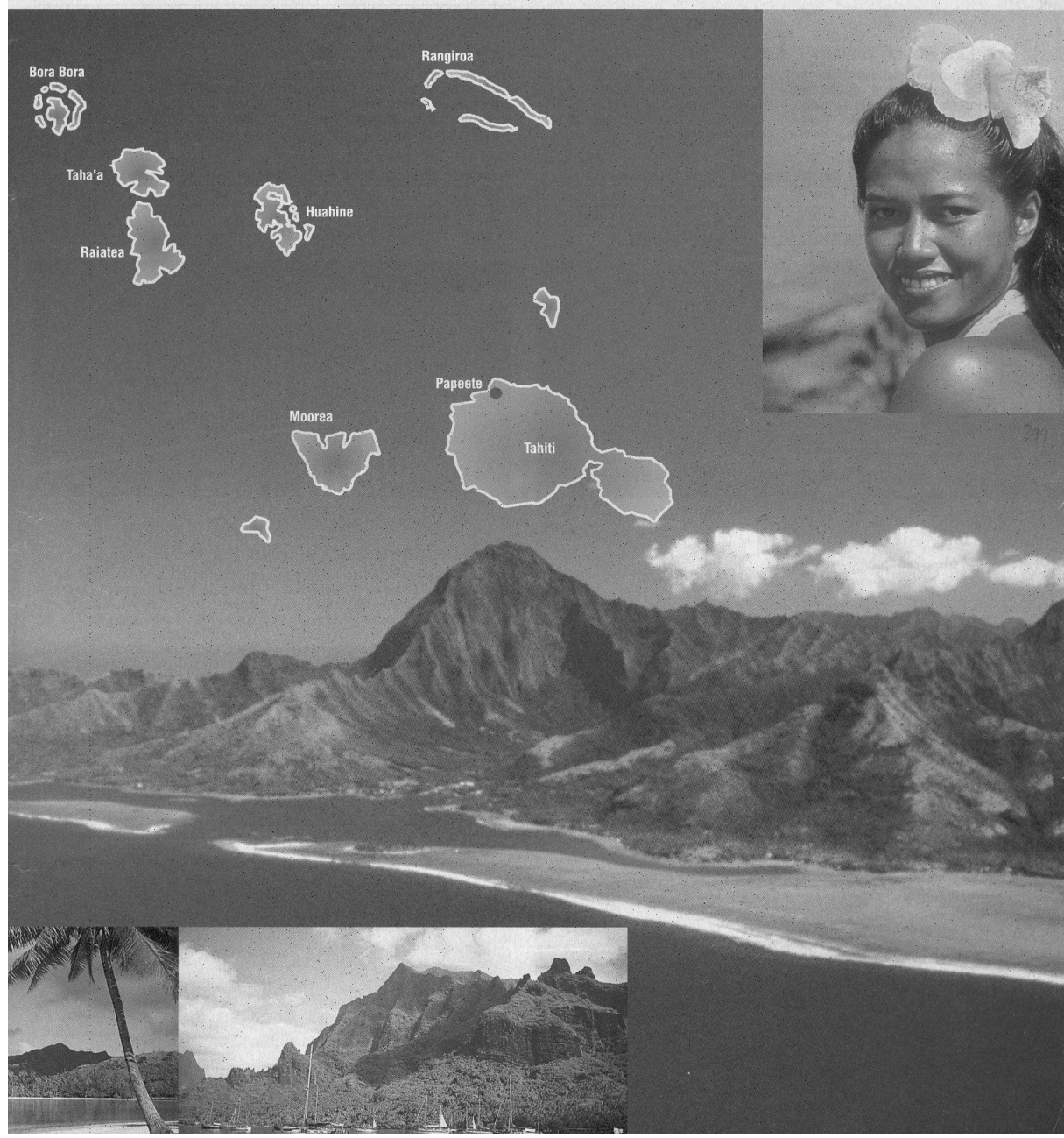

Figure 4 Map woman

Bora - Worth knowing', for example, we read the following opening line: 'Probably more has been written about Bora Bora than about any other South Sea island. Even from a distance she reveals her overwhelming beauty ' (Pacific Jet, 1997 / 98: 80) (authors' emphasis). The text is framed by a map of the island and 
a photograph. The photograph does not, as one might expect, show the island's dramatic landscape but instead features the stereotypical exotic image of a lightly dressed Polynesian woman. Placing the photograph of a local woman next to a map is a common practice in the South Sea brochures. In some instances, the female image is actually pasted into the map where it appears amongst (other) island symbols. Figure 4 provides an example of this technique. The entire photo montage places the natural attractions of these islands within a distinct female context. These manipulative graphics, however, do not just emphasise a feminine place identity, but in the process also degrade the female Polynesian to an aesthetic landscape feature - an essentially geographic tourist attraction.

The German language distinguishes between masculine, feminine and neuter nouns and signifies this grammatical gender through the use of an appropriate attribute (der, die or das). Thus 'the South Sea', translated as die Südsee, carries the singular feminine attribute. All brochures surveyed prefer to use this prosaic term over the more geographic and male gendered descriptor der Südpazifik (the South Pacific). The South Sea is distinctively feminine, even in a grammatical sense.

\section{Islands of seduction}

Having established and marked the destination gender through the use of female imagery, the brochure texts proceed to project the reader into the role of seduced connoisseur. Thus he (?) will visit an island world where 'nature presents herself in accomplished beauty' (Tischler, 1997/98: 18). The outcome of this journey seems to be determined at the outset: 'You too will succumb to the charm

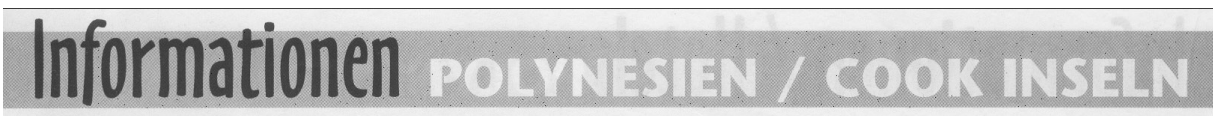

Hier angekommen, wird man mit Blumenkränzen und einem freundlichen "Kia Orana", was soviel wie "mögest Du lange leben" bedeutet, begrüßt. Diese Inseln gehören zu den wenigen Plätzen unserer Erde, die wirklich noch unverdorben sind. Hier gibt es keine Hochhäuser oder Verkehrsampeln. Die Cook-Insulaner sind für ihre aufrichtige, unverdorbene Art und ihren zwanglosen Lebensstil bekannt. Den Fremden erwarten viele Naturschönheiten, die mit der Freundlichkeit der Insulaner um die Gunst der Besucher wetteifern.
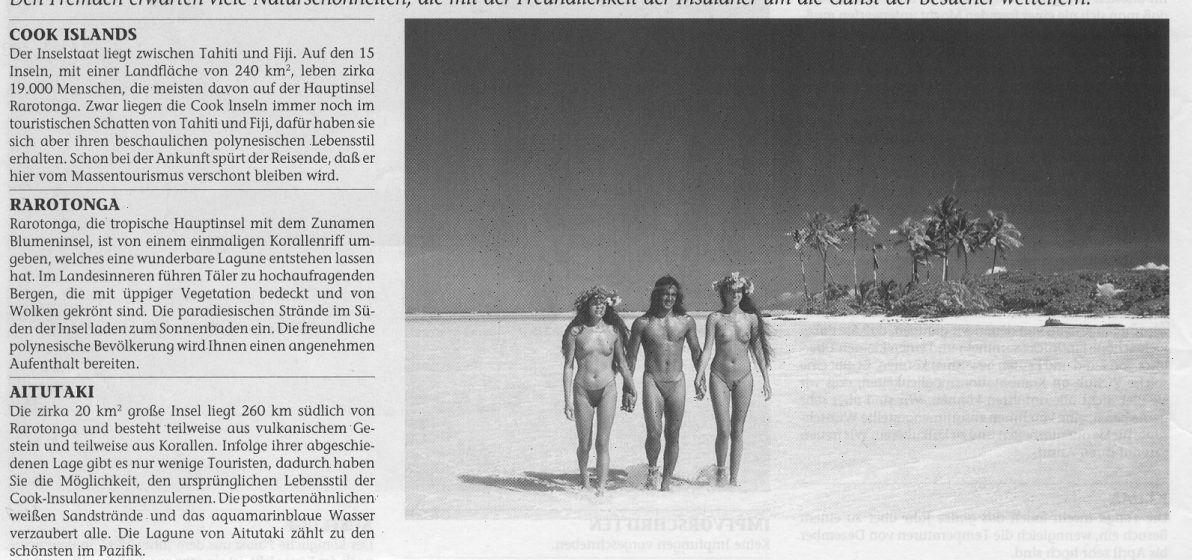

Figure 5 Undressed bodies 
of this island' (Pacific Jet, 1997 / 98: 82). 'Let yourself [therefore] be seduced by the diversity and variety of French Polynesia's island world ...' awaiting you with a '... unique spectrum of natural beauties and recreational activities' (Feria, 1997: 6). The use of a local language greeting creates a suggestive human link in the following tour description:

Bula! You will often hear this welcome greeting of the friendly Fijians during your stay. In the early morning you arrive at Viti Levu, the main island of the Fiji Islands. Look forward to five beautiful days on the island of gentle seduction. (CA Ferntouristik, 1997/98: 212) (authors' emphasis)

The photograph presented in Figure 5, however, leaves little doubt about the suggestive intent of the destination marketers. This opening page on the Cook Islands goes one step further in its blatant exploitation of the indigenous feminine image. Under the heading 'Information Polynesia / Cook Islands' we view the photograph of a European male, by implication a tourist, wading the crystal waters of a lagoon while holding hands with two young women who wear nothing apart from a tiny bikini slip. The women's headdresses of exotic flower garlands suggest that they are locals. The same brochure features a similarly blatant shot on the preceding 'Tonga' page. This time, however, two topless, flower adorned women wander along a coral key on their own. Between their bronzed bodies is just enough open space to allow the reader's fantasy to project itself into the picture.

There is a stark contrast between these images of European fashion and the local bathing culture. On Pacific islands, local women very rarely wear Western-style swimming costumes. They certainly never walk immodestly along a beach in a topless outfit. Raratongan girls commonly swim wearing a pareu, the traditional wrap around dress which covers most of the body. An official publication of the Cook Islands Tourist Authority (1997: 2) devotes a special paragraph to dress:

Although the dress code is informal, we do ask that brief attire should not be worn when visiting town or villages. A respectable standard of dress is required when attending church services. Nude or topless sunbathing will cause offence.

The feminine island image of inhibition, availability and seduction presented in the surveyed brochures is a myth which permeates much of the advertising discourse on the South Sea. It relates to another important symbolic dimension of the liminal experience in which the flight to the South Sea represents the ritualistic search for a distant land of myth and Utopia, upon which dreams are based.

\section{The Stuff of which Dreams are Made}

Dreams are a critical element in the marketing process, as Glasser (1975: 23) noted: 'You don't sell a product; you sell a dream'. The fabrication of consumer dreams is central to the promotion of South Pacific islands as exotic tourism destinations. Under the heading 'The dream islands of the South Sea', the Kuoni brochure (1997/98: 81) introduces the region in the following manner: 
In the beginning there was the ocean and the volcanoes. But over millennia the magical South Sea was created from these. Already the discoverers Captain Wallis, Captain Bougainville and Captain Cook related the fascination and the indescribable beauty of the Pacific island world. Who does$\mathrm{n}$ 't think there of the glittering sand beaches, turquoise lagoons and colourful orchids? The islands of the South Sea - this is the stuff of which dreams are made. (authors' emphasis)

If one promotional metaphor dominates the brochure texts, it is the theme of 'dreaming'. Dreams are omnipresent: the phrase features in all brochures, often in the form of metaphor but also as a dominant descriptor for the whole region itself. Brochure readers, thus, will encounter 'dream beaches' and 'dream ships' in the 'dream islands of the South Sea'. Various operators offer marriage services for tourist couples such as the 'dream wedding in Fiji' arranged by Austrian agent Tischler (1997/98: 10). The Swiss hiking tour specialist Baumeler (1997: 200) even went so far to name its Oceania tour 'Hiking Dream South Sea'.

The metaphor has obviously also left a few marks on local maps and charts. German tour operator Marco Polo (1997: 272) will take you to the Fijian 'Daydream Island', while Austrian company Pacific Jet (1997/98: 63) challenges prospective customers to 'explore the great diving grounds of northern Fiji such as the "great white wall" or the "golden dream"'. There is no doubt: dreams can be found everywhere in the South Sea.

\section{From fantasy to consumption: Dreams become reality}

Creating customer dreams is only the first step in the successful promotion of a destination. To achieve their ultimate marketing goal, the brochure designers must also convince readers to turn their imaginary dream journey into actual travel. Once created, dreams are placed in a particular geographical or cultural setting where they can be localised and, hereby, ultimately consumed. Often a dramatic writing style supports this strategy. An excerpt from a Swiss brochure:

Volcanoes, hills and mountains which rise above exotic tropical forests. Emerald lagoons, sparkling white beaches fringed by palms swaying gently in the wind ... A dream? No! - the legendary islands of Tahiti. Illustrious names such as Tahiti, Moorea, Bora Bora, Huahine and Rangiora . . . (Rast Reisen, 1997/98: 80) (authors' emphasis)

Most brochures elevate the South Sea dream to the level of a universal longing which every reader naturally experiences and, therefore, ultimately must realise. Thus, to dream of the South Sea seems natural, despite the region's geographic remoteness. Rhetorical questions are typical of this type of suggestive narrative: 'Who doesn't dream of the South Sea - of the small islands within the endless expanse of the Pacific ...' (Feria, 1997: 10). Hotelplan (1997/98: 72) endows the promoted dream with a subtly erotic, subliminal power by promising that ' . . . everything matches your most secret South Sea dream'. Those caught unaware of this universal longing might feel inferior when they read an introductory paragraph such as this: 
Some names have long had a strong attractive power, images arise in the mind, dreams and longings awake. Tahiti, Moorea, Bora Bora. Who doesn't know them, these names? (CA Ferntouristik, 1997/98: 186) (authors' emphasis)

Advertisers use various techniques to transpose the South Sea dream from the diverse spheres of fantasy to the concrete world of commercial consumption. The most commonly employed strategy lures potential tourists with the prospect of a status enhancement. A German study tour operator challenges brochure readers with the following imperative phrase:

This all-encompassing Pacific study tour introduces you to the many faces of the South Sea dream. Here you still are sincerely welcomed ... Move from being a South Sea dreamer to becoming a witness of this so different wonderful world. (Studiosus, 1997: 368) (authors' emphasis)

Some brochures grant a special status to customers with travel experience: 'For advanced South Sea travellers and South Pacific repeaters, the islands of Western Samoa and Tonga should be mentioned' (CA Ferntouristik, 1997/98: 169). Whoever eventually gains entry to the illustrious circle of South Sea connoisseurs will be rewarded with personal entry to one's own dream land. Only then the shift from fantasy to consumption will have been successfully completed and, naturally, it will amount to nothing less than a trustworthy 'dream deal'. Consider the opening lines of the catalogue of Switzerland's market-leading Oceania specialist:

Dear Oceania friend, excuse this salutation - but let's just assume that you have discovered your heart for these fantastic countries - or even have visited there once. We wish that you finally get to know your dream landpersonally - of course. And this at dream-like prices. Promised! (Knecht Reisen Ozeanien, 1997/98: 21)

Obviously, the game of status elevation plays a key role in convincing people to fulfil their most distant dreams. To the same effect the brochures often associate the South Sea dream with famous or popular personalities, therefore endowing it with some elusive authority.

\section{Famous dreams}

In his historic analysis of the mythical South Sea image, Cohen (1982) points to the influence artists and writers had in popularising life on the South Pacific islands. He mentions such famous names as Paul Gauguin, Robert Louis Stevenson, Mark Twain, Herman Melville, Jack London and James Michener. Cohen claimed that the tourism industry, as it penetrated the South Pacific Islands, built its advertising campaigns upon an already popularised romantic image. The findings of our brochure analysis clearly support this claim.

German-language brochures frequently refer to famous personalities from Europe and North America associated with the South Sea. Such references usually authenticate the natural and cultural attractions of the region. The following quotation is typical:

Adventurous explorers such as James Cook, globe-trotting authors such as Jack London, artists such as Paul Gauguin and actors such as Marlon 


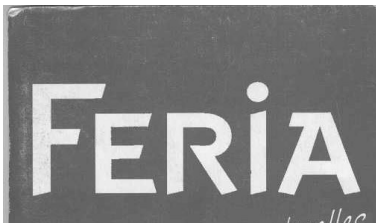

Stank für Individuelles
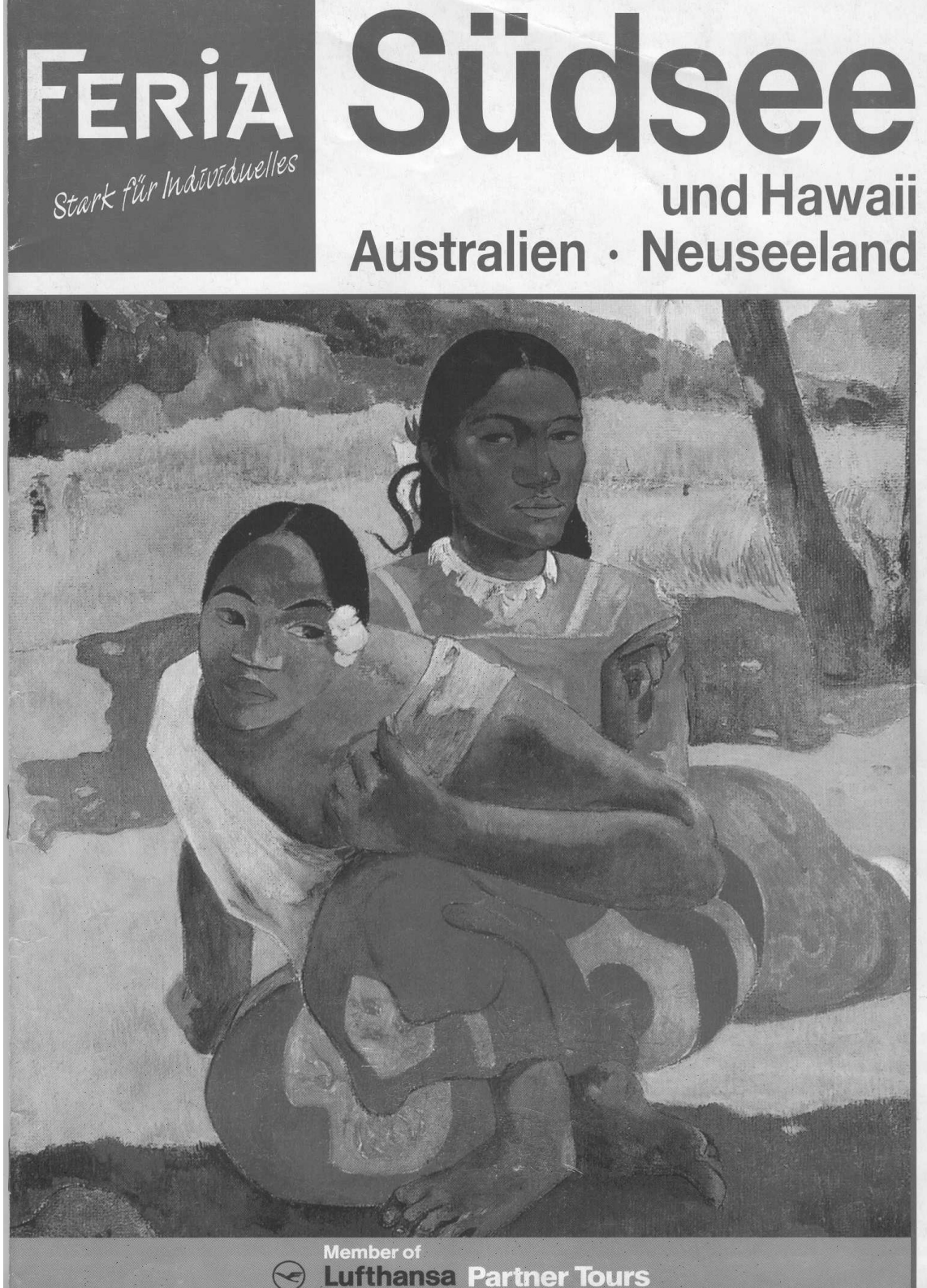

Figure 6 Gauguin's young Polynesian women

Brando - they all were enthusiastic about the charm of the graceful, happy people and the fabulous landscapes. (Hotelplan: 1997/98: 77)

None of these stereotypical claims, however, acknowledges the fact that many authors who visited the South Sea in search of its paradise image actually 
returned disillusioned. Jack London was one of them. Travel writer Paul Theroux's (1993) book The Happy Isles of Oceania, a recent contribution to the Pacific adventure theme, traces various other famous South Sea dreams and suggests that many resulted in bitter disappointment.

\section{Famous nymphs}

Probably the most famous dream seeker was the artist Paul Gauguin who painted his best known works in French Polynesia. Gauguin reached the shores of Tahiti about 50 years after author Herman Melville had left in deep disillusionment. The artist's intention was clear, expressed most vividly through his own words, quoted by Daws (1980: 95): 'These nymphs, I want to perpetuate them with their golden skins, their searching animal odour, their tropical savours'. Gauguin soon became familiar with the darker aspects of colonial Tahitian life, and, deeply disillusioned, wrote the following lines:

Many things that are strange and picturesque existed here once, but there are no traces of them left today; everything has vanished . . . There is so much prostitution that it does not exist . . . one only knows a thing by its contrary, and its contrary does not exist. (Daws, 1980)

Gauguin went on to live in the Marquesa Islands where he hoped to still find the aesthetic dream for which he had come to search. It is this powerful dream, or rather a romanticised distortion thereof, for which the artist has been remembered ever since his expressive paintings first reached the famous art galleries of Europe.

The tourist brochures surveyed are no exception when it comes to romanticising Gauguin's art work and Polynesian experience. The famous painter plays an important part in the cultural marking of Tahiti in particular. The island itself is sometimes likened to the artist's paintings. Visitors are encouraged to take a stroll through the city of Papeete 'in search of the wonderful world of colour which once enchanted Gauguin' (Jumbo Touristik, 1995/96: 70). Another brochure opens its Tahiti page with the bold headline 'In the footsteps of Paul Gauguin ...' (Knecht Reisen Ozeanien, 1997/98: 102). The German travel agent Feria goes one step further still by choosing a famous Gauguin painting of two young and beautiful Polynesian women for the front cover of its South Sea catalogue (Figure 6). In this instance, art has become a cultural marker not just for Tahiti but the entire region. Gauguin's life and work, conveniently romanticised, indeed represents the most famous dream of the South Sea paradise.

According to the brochures, the islands always deeply influenced their famous visitors. The apparent fascination with Polynesia is often likened to an irresistible power: 'Even the rough seamen of the Bounty and the artist Gauguin fell for the magic spell of Tahiti' (Pacific Jet, 1997/98: 72). The constructed fascination serves to justify not only the powerful myth of a romantic paradise but also the ever-present cliché of an erotic dream destination. Obviously, there is no resisting the magic spell of the South Sea dream, not even for the famous Paul Gauguin.

\section{Where the dreams live}

To meet customer expectations, promoted dream images must also be matched by the physical reality of the tourism resource (Cloke \& Perkins, 1998, 2002; Cohen, 1982). Figure 7 illustrates how the South Sea dream is re-enacted 


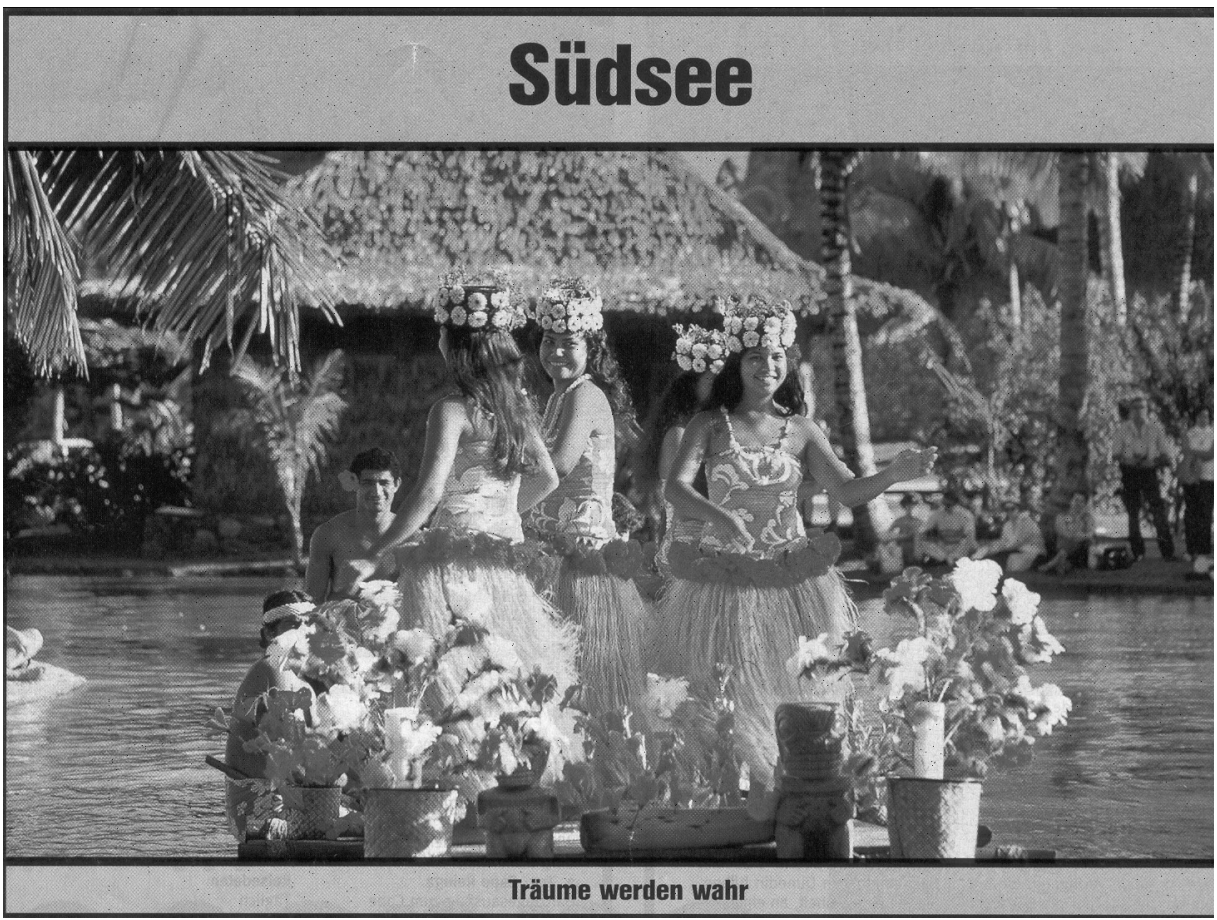

Figure 7 Dancers - dreams become real

through the ritual staging of a pseudo-event resembling an ancient cult. A group of flower-adorned female dancers seem to float on the blue waters of what is presumably a hotel swimming pool. The image appears under the large heading 'South Sea' and is subtitled with the brief caption 'Dreams become real'. In the background, we can only just decipher the blurred images of tourists who, in the role of spectators, participate in this ritual enactment of 'their' dreams. Magic is an obvious element in this particular form of ritual dream realisation. Visually, such magic is conveyed by the imaginative staging of the event.

The ways in which tourism-led changes are made consistent with marketing images are also signified by a typical element of French Polynesia's resort architecture: the over-water bungalow. The first hotel rooms suspended above the waters of a lagoon originated in the island of Moorea, according to the brochure of CA Ferntouristik (1997/98: 192). Figure 8 presents a brochure photograph of an over-water bungalow village. A wooden access bridge leads the viewer's mind towards the Pacific's blue horizon, literally beyond the land's outermost margin, to a comfortable holiday home. In a physical sense, one could not get further away from everyday reality. In a symbolic sense, however, one could not get closer to the enduring Utopian dream of a South Sea paradise.

The ubiquitous dream metaphor is the most persistent common denominator of the brochures' advertising narratives and connects the South Sea's core image to an ancient myth. The promise of a distant paradise, Utopian in character, builds upon a romanticised organic image which continues to be popularised by 


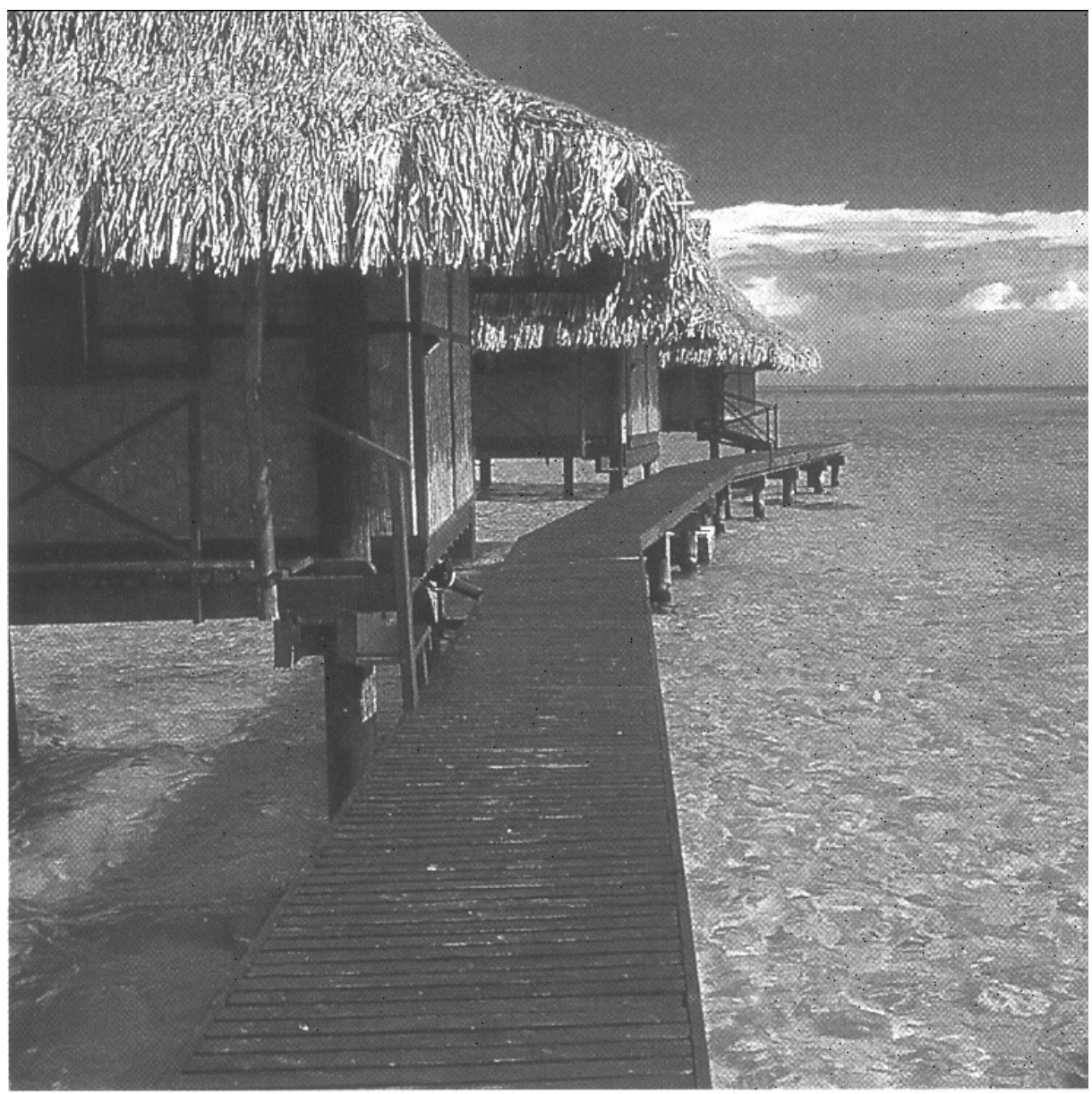

Figure 8 Over-water bungalow village

artists, writers and popular culture. Through tourism advertising, however, the Utopian myth is being converted into a marketable consumer product. For this purpose, dreams have to be traceable, paradise has to become discoverable, Utopia must be realised.

No analytical summary could illustrate this symbolic transformation process better than the brochures themselves. Under the heading 'Sea of Dreams', Kiwi Tours (1996: 46) exposes the tourism product of a South Sea paradise more imaginatively than these authors ever could:

There is a place where the dreams live. Where nature lavishes herself in beauty. Where white beaches draw a sparkling circle between the intense turquoise of the lagoons and the deep green of the palms. South Sea - the name alone sounds like warm wind and soft sea water. On this journey you will experience the pearls of the Pacific: Hawaii, Fiji, Cook Islands and Tahiti. Joyful, friendly people will greet you with fragrant flower leis. To take a deep breath and simply let oneself fall. Welcome to paradise. 


\section{Conclusion}

Our critical reading of German-language brochures has sketched a core place image for the South Sea. This centres around the enduring dream of a feminised, exotic yet comforting paradise which occupies the outermost margin of Eurocentric imagination and geography. Built upon an already widespread, alluring myth, this image strongly reflects the romanticising influences of colonial exploration, high art and popular culture. The South Sea's place image gains its dynamic power, however, from the tension which constantly arises between the separate realities of a familiar Centre and the exotic Other.

Recognising this tension as a marketable symbolic item, the tourism industry sells places to people by promoting temporary and safe experiences of the exotic Other. Thus, the enduring dream of an earthly paradise, refined and adapted to the requirements of a mass tourist market, plays a key role in the promotion of the South Sea as a travel destination. Portrayed as easy-going, uninhibited, happy service people, the traditional Pacific peoples and cultures have become yet another crucial element in this marketing process. Consequently, the South Sea's still young tourism sectors are currently perpetuating a romanticised, distorted and essentially neocolonial service culture. This culture, in turn, reflects, amongst other influences, the outdated expectations forced upon it by the sexist attitudes evident in tourist brochures.

We agree with Goss (1993: 672) who concluded that advertisements 'tell us more about the culture that produced them than about that which they attempt to sell'. Thus, tourism is an important factor not only in the ongoing commodification of host places but clearly also for the shaping of cultural identity in source regions, in this case Central Europe. Goss (1993: 686) also argues that 'tourism becomes merely the reading of touristic signs emptied of all meaning except the signification of difference. [Consequently] . . . a place or region is reduced to a signifier of alterity'. In this latter regard we take a different position arguing that tourism and the imaginary geographies it produces also help to recontextualise elementary human longings otherwise neglected in modern everyday life. In particular, our analysis of brochures has confirmed the elements of ritual, myth and dreams of Utopia as three core symbols of Central European holiday culture. The enduring appeal these symbolic elements hold for the human consciousness is critical to a deeper understanding of the transformative processes from which imagined geographies, such as the South Sea dream, arise.

\section{Acknowledgements}

Thanks to Suzanne Vallance of the Social Science, Tourism and Recreation Group, Lincoln University, for her research assistance.

\section{Correspondence}

Any correspondence should be directed to Dr Harvey C. Perkins, Social Science, Tourism and Recreation Group, Environment, Society and Design Division, PO Box 84, Lincoln University, Canterbury, New Zealand (Perkins@ lincoln.ac.nz). 


\section{Notes}

1. The term brochure includes material ranging in size from one page information and advertising sheets to much longer documents. Some of the brochures used in this study were as long as 400 pages, divided into several sections, with one such section carrying the title 'South Sea'.

2. While in English the South Pacific Ocean is often referred to as the 'South Seas', in German it is typically expressed in the singular die Südsee, the South Sea. Given that our case study data were produced in German-speaking countries we have used the singular form throughout the paper.

3. None of the surveyed travel catalogues states the place of publication or the author(s).

\section{References}

Adams, K. (1984) Come to Tana Toraja, land of the heavenly kings. Travel agents as brokers in ethnicity. Annals of Tourism Research 11, 460-85.

Boorstin, D.J. (1964) The Image: A Guide to Pseudo-Events in America. New York: Harper and Row.

Bougainville, L. (1772) A Voyage Round the World. Performed by Order of His Most Christian Majesty, in the Years 1766, 1767, 1768 and 1769 (trans. J.R. Forster). London: Nourse and Davies.

Britton, R.A. (1979) The image of the Third World in tourism in marketing. Annals of Tourism Research 6, 318-29.

Britton, S. G. (1982) The political economy of tourism in the Third World. Annals of Tourism Research 9, 331-58.

Bruner, E. (1991) Transformation of self in tourism. Annals of Tourism Research 18, 238-50.

Buck, R. (1977) The ubiquitous tourist brochure, explorations in its intended and unintended use. Annals of Tourism Research 4, 195-207.

Cameron, I. (1987) Lost Paradise: The Exploration of the Pacific. London: Century Hutchinson.

Cloke, P. and Perkins, H.C. (1998) 'Cracking the canyon with the awesome foursome': Representations of adventure tourism in New Zealand. Environment and Planning D: Society \& Space.

Cloke, P.J. and Perkins, H.C. (2002) Commodification and adventure in New Zealand tourism. Current Issues in Tourism 5 (6), 521-49.

Cohen, C.B. (1995) Marketing paradise, making nation. Annals of Tourism Research 22, 404-21.

Cohen, E. (1972) Toward a sociology of international tourism. Social Research 39, 164-82.

Cohen, E. (1979) A phenomenology of tourist experiences. Sociology 13, 179-201.

Cohen, E. (1982) The Pacific Islands from utopian myth to consumer product: The disenchantment of paradise. Cahiers du Tourisme (série B) 27.

Cohen, E. (1985) Tourism as play. Religion 15, 291-304.

Cohen, E. (1988) Authenticity and commoditization in tourism. Annals of Tourism Research $15,371-86$.

Cohen, E. (1995) Contemporary tourism - trends and challenges. Sustainable authenticity or contrived post-modernity? In R. Butler and D. Pearce (eds) Change in Tourism: People, Places, Processes (pp. 12-29). London: Routledge.

Cook Islands Tourist Authority (1997) The Cook Islands: A Special Place. A Special People. A Special Magic. Auckland: Scenix Marketing.

Corkery, C. and Bailey, A. (1994) Lobster is big in Boston, postcards, place commodification and tourism. Geojournal 34 (4), 491-8.

Crang, M. (1996) Envisioning urban histories: Bristol and palimpsest, postcards and snapshots. Environment and Planning A 28, 429-52.

Crick, M. (1989) Representations of international tourists in social sciences: Sun, sex, sights, savings and servility. Annual Review of Anthropology 18, 307-44.

Dahles, H. and Van Meist, T. (2000) Local perspectives on global tourism in Southeast Asia and the Pacific region: Introduction. Pacific Tourism Review 4, 53-62. 
Dann, G. (1993) Advertising in tourism and travel: Tourism brochures. In M. Khan, M. Olsen and T. Var (eds) VNR's Encyclopaedia of Hospitality and Tourism (pp. 893-901). New York: Van Nostrand Reinhold.

Dann, G. (1996) The people of tourist brochures. In T. Selwyn (ed.) Myth and Myth Making in Tourism (pp. 61-81). Chichester: Wiley.

Daws G. (1980) A Dream of Islands. New York: Norton.

de Kadt, E. (1979) Tourism: Passport to Development? New York: Oxford University Press.

Dietvorst, A.G.J. and Ashworth, G.J. (1995) Tourism transformations: An introduction. In G.J. Ashworth and A.G.J. Dietvorst (eds) Tourism and Spatial Transformations: Implications for Policy and Planning (pp. 1-12). Wallingford: CAB International.

Felsenmeier, D. and MacKay, K. (1996) Deconstructing destination image construction. Review de Tourisme 2, 37-43.

Garcia, A. (1988) And why don't you go to the Seychelles? In P. Rossel (ed.) Manufacturing the Exotic (pp. 93-115). Copenhagen: International Work Group for Indigenous Affairs.

Giddens, A. (1991) Modernity and Self-Identity: Self and Society in the Late Modern Age. Cambridge: Cambridge University Press.

Glasser, R. (1975) Life force or tranquilizer. Society and Leisure 7 (3), 17-26.

Goss, J. (1993) Placing the market and marketing place: Tourist advertising of the Hawaiian Islands, 1972-1992. Environment and Planning D: Society and Space 11,663-88.

Gottlieb, A. (1982) Americans' vacations. Annals of Tourism Research 9, 165-87.

Graburn, N. (1989) Tourism, the sacred journey. In V. Smith (ed.) Hosts and Guests. The Anthropology of Tourism (2nd edn) (pp. 21-36). Philadelphia: University of Pennsylvania Press.

Gregory, D. (2000) Regions and regional geography. In R.J. Johnston, D. Gregory, G. Pratt and M. Watts (eds) The Dictionary of Human Geography (4th edn). Oxford: Blackwell.

Gunn, C. (1972) Vacationscape. Austin: Bureau of Business Research, University of Texas.

Habermas, J. (1981) Theorie des Kommunikativen Handels. Frankfurt: Suhrkamp.

Hughes, G. (1992) Tourism and the geographical imagination. Leisure Studies 11, 31-42.

Kassarjian, H.H. (1977) Content analysis in consumer research. Journal of Consumer Research: An Interdisciplinary Quarterly 4 (1), 8-18.

Kay, R. (1993) Fiji - A Travel Survival Kit (3rd edn). Hawthorn: Lonely Planet.

Keenan, D. (1997) Shark victim will survice, but looses leg. The Press (Christchurch, NZ), June 19, 1 .

King, B.M. (1997) Creating Island Resorts. London: Routledge.

King D. and Stewart, W.P. (1996) Ecotourism and commodification: Protecting people and places. Biodiversity and Conservation 5, 293-305.

Lea, J. (1988) Tourism and Development in Third World Countries. New York: Routledge.

Lewis, P.F. (1979) Axioms for reading the landscape. In D. Meinig (ed.) The Interpretation of Ordinary Landscapes (pp. 11-32). New York: Oxford University Press.

MacCannell, D. (1976) The Tourist. A New Theory of the Leisure Class. New York: Schocken.

MacCannell, D. (1992) Empty Meeting Grounds: The Tourist Papers. London: Routledge.

MacDonald, S. (1997) A peoples story: Heritage, identity and authenticity. In C. Rojek and J. Urry (eds) Touring Cultures: Transformation of Travel and Theory. London: Routledge.

Meethan, K. (2001) Tourism in Global Society - Place, Culture, Consumption. New York: Palgrave.

Moeran, B. (1983) The language of Japanese tourism. Annals of Tourism Research 10, 93-108.

Moore, A. (1980) Walt Disney World: Bounded ritual space and the playful pilgrimage centre. Anthropological Quarterly 53 (4), 207-18.

Moser, C.O.N. (1993) Gender Planning and Development - Theory, Practice and Training. London: Routledge.

Müller, H. and Thiem, M. (1995) Tourism and cultural identity. Revue de Tourisme 4, 15-19.

Papson, S. (1981) Spuriousness and tourism. Annals of Tourism Research 8, 220-35.

Parker, I. (1992) Discourse Dynamics: A Critical Analysis of Social and Individual Psychology. London: Routledge.

Pearce, P.L. (1982) Perceived changes in holiday destinations. Annals of Tourism Research 9 , 145-64. 
Robertson, G. (1955) An Account of the Discovery of Tahiti: From the Journal of George Robertson, Master of HMS Dolphin. London: Folio.

Rudkin, B. and Hall, C.M. (1996) Health and tourism in the Pacific. In C.M. Hall and S.J. Page (eds) Tourism in the Pacific: Issues and Cases (pp. 130-45). London: International Thomson Business.

Scheyvens, R. (2002) Tourism for Development: Empowering Communities. Harlow: Prentice Hall.

Schöllmann, A., Perkins, H.C. and Moore, K. (2000) Intersecting global and local influences in urban place promotion: The case of Christchurch, New Zealand. Environment and Planning A 32, 55-76.

Schöllmann, A., Perkins, H.C. and Moore, K. (2001) Rhetoric claims-making and conflict in touristic place promotion: The case of central Christchurch. Tourism Geographies 3 (3), 300-325.

Selby, M. and Morgan, N.J. (1996) Reconstruing place image: A case study of its role in destination market research. Tourism Management 17 (4), 287-94.

Selwyn, T. (1990) Tourist brochures as post-modern myths. Problems of Tourism 13 (3/4), 13-26.

Selwyn, T. (1993) Peter Pan in South East Asia. Views from the brochures. In M. Hitchcock, V. King and M. Parnwell (eds) Tourism in South East Asia (pp. 117-37). London: Routledge.

Selwyn, T. (ed.) (1996) The Tourist Image: Myth and Myth Making in Tourism. Chichester: Wiley.

Shields, R. (1991) Places on the Margin. Alternative Geographies of Modernity. London: Routledge.

Smith, B. (1989) European Vision and the South Pacific. Melbourne: Oxford University Press.

Soule, M.E. (1995) The social siege of nature. In M.E. Soule and G. Lease (eds) Reinventing Nature? Responses to Postmodern Deconstruction (pp. 137-70). Washington: Island Press.

Stanley, D. (1993) South Pacific Handbook (5th edn). Chico: Moon.

Stymeist, D.H. (1996) Transformation of Vilavilairevo in tourism. Annals of Tourism Research 23, 1-18.

Swaney, D. (1994) Samoa - Western Samoa and American Samoa: A Lonely Planet Travel Survival Kit. Hawthorn: Lonely Planet.

The Press (1997) Fiji leaseholder decision delayed. The Press (29 November), 17.

Theroux, P. (1993) The Happy Isles of Oceania: Paddling the Pacific. Fawcett.

Thurot, J.M and Thurot, G. (1983) The ideology of class and tourism: Confronting the discourse of advertising. Annals of Tourism Research 10, 173-89.

Urry, J. (1990, 2002) The Tourist Gaze. London: Sage.

Urry, J. (1995) Consuming Places. London: Routledge.

Valentine, G. (1999) Imagined geographies: Geographical knowledge of self and other in everyday life. In D. Massey, J. Allen and P. Sarre (eds) Human Geography Today. Cambridge: Polity Press.

Wagner, U. (1977) Out of time and space: Mass tourism and charter trips. Ethnos 42 (1/2), $38-52$.

Wilson, D. (1994) Probably as close as you can get to paradise: Tourism and the changing image of the Seychelles. In A.V. Seaton (ed.) Tourism: The State of the Art (pp. 765-74). Chichester: Wiley.

\section{Appendix: Reference List of Surveyed Travel Catalogues}

Baumeler (1997) Wanderferien. Gültig bis 31. März 1998. ${ }^{3}$

CA Ferntouristik (1997/98) Australien, Neuseeland und Südsee, 2. Auflage gültig für Buchungen ab 15.1.97.

Feria (1997) Südsee und Hawaii, Australien, Neuseeland. Sommer 1997.

GeBeCo (1997) Reisen '97. Neuseeland, Südsee entdecken .

Hotelplan (1997/98) Australien Neuseeland. Sie werden kopfstehen. Koalas. Kiwis. Kängeruhs. Und die Südsee dazu. Fidschi. Tahiti. Cook Islands. April 97 bis März 98.

Imholz (1997/98) Australien Neuseeland Südsee, April 97 bis März 98. 
Jumbo Touristik (1995/96) Australien Neuseeland Südsee, Kreuzfahrten rund um die Welt, Rundreisen und Badeferien, Trauminsel Kombinationen.

Kiwi Tours (1996) Neuseeland Australien Südsee, zusammen mehr erleben.

Klingenstein (1996) Klingenstein E Partner Studienreisen. Kulturelles Leben live, Afika, Asien, Amerika, Australien, Pazifik - mit Wanderstudienreisen.

Knecht Reisen Ozeanien (1997/98) Ferienprogramm 97/98 Ozeanien, Australien, Neuseeland, Südsee.

Kuoni (1997/98) Australien Neuseeland Südsee, Kuoni: A World of Difference. April 1997 März 1998.

Marco Polo Reisen (1997) Gesammtkatalog 1997. Studien-, Natur- und Erlebnisreisen. Individuelle Anschlussprogramme.

Meier's Weltreisen (1997) Australien, Neuseeland, Südsee. Urlaub mit der LTU Gruppe, Sommer 1997.

Pacific Jet (1997/98) Südsee und Neuseeland. Best of South Pacific, Südsee: Fiji, Cook Inseln, Tahiti, Neukaledonien, Tonga, Westsamoa, Vanuatu, Osterinseln, Neuseeland: Nord- und Südinsel.

Rast Reisen (1997/98) Australien. Australien - Rundreisen von A bis Z, Neuseeland für Naturliebhaber, Südsee Exotisches Inselparadies. Januar 97 bis März 98.

Studiosus (1997) Studienreisen Afrika Amerika Asien Australien. Einander verstehen: Urlaub mit Studiosus.

Tischler (1997/98) Südsee Neuseeland Australien.

Tui (1997) Schöne Ferien, Hauptkatalog. 